IRA International Journal of Management \& Social Sciences ISSN 2455-2267

Vol. 14, Issue 02 (Special Issue) pg. 101-144.

International Conference on Wellbeing: Lifespan Perspectives $\Xi$ Practices for Sustainable

Communities, 2019.

\title{
Survey on Quality of Life Profiling of Frontline Forest Personnel of Manas National Park
}

Dr Sangeeta Goswami ${ }^{1}$, Bibhuti P. Lahkar ${ }^{3}$, Binita Baruwati ${ }^{3}$, Bipul Das ${ }^{3}$, Kamal Machari ${ }^{3}$, Ranen Basumatary ${ }^{3}$, Sanjib Daimari ${ }^{3}$, Silas Basumatari ${ }^{3}$, Sudip Kanta Basistha ${ }^{3}$, Dr D Duttaroy $^{2}$, Abhijit Goswami ${ }^{2}$, Sandamita Choudhury², Ankita Kakati ${ }^{2}$, Deepankar Bhattachryja ${ }^{2}$

${ }^{1}$ Couselling Psychologist \& President, MIND India, Guwahati 781003, Assam India.

${ }^{2}$ Survey Team, MIND India, Guwahati 781003, Assam India.

${ }^{3}$ Survey Team, Aaranyak Programme, Assam, India.

DOI: $10.21013 /$ jmss.v14.n2sp.p13

() Authors.

Type of Review: Peer Reviewed under the Responsibility of the conference's Scientific Committee.

Disclaimer: The copyright to this work is retained by the authorship. This work contains the opinions $\Xi^{\circ}$ views of the authorship solely and the same are not the views or opinions of the IRA. IRA disclaims of any harm or loss caused due to the published content to any party. 


\title{
SURVEY ON QUALITY OF LIFE
}

\author{
PROFILING OF
}

FRONTLINE FOREST PERSONNEL

$O F$

MANAS NATIONAL PARK

REPORT

Aaranyak Programme

with technical support of

\section{MIND India}

MIND India

Institute of Positive Mental Health

187, Maniram Dewan Road

Chandmari Guwabati 781003

Assam India

$03612667269 / 9864067594 / 9864110634$

www.mindindia.org 


\section{ABOUT THE SURVEY}

This report is on Survey on Quality of Life Profiling of Frontline Forest Personnel of Manas National Park. The report has been produced as part of Manas Tiger Conservation Programme (MTCP) activities. MTCP, led by Aaranyak and being implemented in partnership with the Forest Department BTC, Wildlife Conservation Trust, Panthera and Awely, is actively working towards improvement of protection, conservation and community wellbeing in Manas National Park and its fringe areas.

\section{ACKNOWLEDGEMENTS}

With deep gratitude to all those who have contributed towards the success of this project, especially the following:

Swargiary, IFS, CHD, Department of Forest, BTC

Dr. Bibhab Kumar Talukdar, CEO cum Secretary General, Aarnayak

BTC Forest Department

Aaranyak Team

Forest personnel who participated in the survey

Mr M. Firoz Abmed, PhD, Director, Aaranyak

Dr D Duttaroy, Advisor

Aaranyak team

MIND India team

Department of Forest of Assam

Forest personnel who participated in this project 


\section{EXECUTIVE SUMMARY}

\section{INTRODUCTION}

Manas National Park is an UNESCO Natural World Heritage site and a Project Tiger reserve, an elephant reserve and a biosphere reserve in Assam, India. Located in the foothills of the Himalayas, it is contiguous with the Royal Manas National Park in Bhutan. The park is known for its rare endangered and endemic wildlife such as the Assam roofed turtle, hispid hare, golden langur and pygmy hog. Manas is also famous for its population of the wild water buffalo.

Presently, Aaranyak is implementing working on a project viz. The Manas Tiger Conservation Programme (MTCP). It is led by Aaranyak and being implemented in partnership with the Forest Department BTC, Wildlife Conservation Trust, Panthera and Awely. The project has been supported by International Union for Conservation of Nature (IUCN). The Goal of the Project is to achieve 50\% increase in tiger population in the next 10 years with enhanced protection measures, research and working on livelihood on the fringe area communities of MNP.

The scope of the survey is to understand the knowledge, skills and attitude of the target group in relation to their work place environment and job responsibilities. The objective is to assess their needs and quality of life in so far as conditions prevalent within the camps and the community in the fringe areas are concerned. The data collected will enable the framing of appropriate measures to enhance holistic growth and efficiency in the functioning of the frontline staff and better protection of MNP.

\section{GEOGRAPHICAL COVERAGE}

The project covered 500 sq. $\mathrm{km}$ area of the park, more than 300 forest personnel are engaged spreading over 60 Camps to protect the rich flora and fauna of this World Heritage Site.

\section{OBJECTIVES}

- $\quad$ To understand the quality of life in so far as conditions prevalent within the camps and the community in the fringe areas are concerned

- To understand the gap in knowledge, skills and attitude of the forest workers in relation to their work place environment and job responsibilities

\section{TARGET GROUP}

The survey included frontline forest personnel working in Manas National Park, under Bodoland Territorial Council, Government of Assam

\section{METHODOLOGY}

\section{PhaseI: Development of Tools}

Focus group discussion was held with the aim to form a repertoire of perceptions, ideas, opinions and beliefs expressed by the group on their way of life and the socio-cultural milieu they hail from, their 
quality of life, as well as their expectations in regard to the training they require to be effective in their job. The discussion was recorded digitally.

\section{Tools developed and adapted:}

- Demographic Profiling of Frontline Forest Personnel of Manas National Park

- Questionnaire for Job Analysis of Frontline Forest Personnel

- Questionnaire on self-efficacy of Frontline Forest Personnel

- $\quad$ General Health Questionnaire (GHQ) an available standardized tool adapted to field needs

\section{Phase II: Implementation of Tools}

Objective 1: To understand the quality of life in so far as conditions prevalent within the camps and the community in the fringe areas are concerned

\section{Tools used:}

- $\quad$ FocusGroup Discussion

- $\quad$ Demographic Profiling of Frontline Forest Personnel of Manas National Park

- $\quad$ General Health Questionnaire (GHQ)

Objective 2: To understand the gap in knowledge, skills and attitude of the target group in relation to their work place environment and job responsibilities

\section{Tools used:}

- Questionnaire for Job Analysis of Frontline Forest Personnel

- $\quad$ Questionnaire on Self-Efficacy of Frontline Forest Personnel

\section{Activity 1: Conduction of FocusGroup Discussion (FGD)}

Focus group discussion was held with the aim to form a repertoire of perceptions, ideas, opinions and beliefs expressed by the group on their way of life and the socio-cultural milieu they hail from, their quality of life, as well as their expectations in regard to the kind training they require to be effective in their job. The discussion was recorded digitally and transcript

\section{Activity 2: Development and adaptation of training tools}

- Demographic Profiling of Frontline Forest Personnel of Manas National Park

- Questionnaire For Job Analysis of Frontline Forest Personnel

- Questionnaire on Self-Efficacy of Frontline Forest Personnel

- $\quad$ Adaptation of Standardized General Health Questionnaire (GHQ) 
The General Health Questionnaire (GHQ) was an adaption of an available standardized test. The other training tools were developed by MIND India based on the focus group discussion and secondary data gathered from Aaranyak.

\section{Activity 3: Training of Manpower}

The selected personnel of Aaranyak were trained to administer the questionnaire in the field to collect appropriate data. The field personnel were handheld by MIND India team during data collection.

\section{Activity 4: Handholding of Aaranyak personnel during data collection}

The field personnel were handhold by MIND India tram during data collection to check the understanding of the Aaranyak team on the method of data collection. This was done as this type of quality of life survey was new for the group

\section{DATA COLLECTION}

Purposive sampling was used to select the forest workers. Purposive sampling is a nonprobability sampling technique in which researcher relies on his/her judgment when choosing members of population to participate in the study. Researchers often believe that they can obtain a representative sample by using a sound judgment and experience. Forest workers present in the camps during the time of data collection were approached for the project. In total 82 forest workers were surveyed.

\section{METHOD OF ANALYSIS}

The collected data was collated and analyzed. The data collected was analysed qualitatively and quantitatively. Content analysis was conducted for the Focus Group Discussion. SPSS was used for the quantitative data collated Job Analysis, Self-Efficacy and General Health questionnaires.

\section{DISCUSSION}

The study reflects that more than $80 \%$ of the forest workers are above the age of 35 years with minimum of 12 years to maximum of 28 years of service. This signifies that the work force is moving towards retirement age while new recruits to substitute them are not in place.

In regard to the educational qualification of the forest workers, majority of the respondents are High School pass. This may be a barrier to enhance working knowledge on the requirements demanded by the fast changing scenario in so far as new technologies to capture, monitor, survey and conserve wildlife is concerned.

The main role \& responsibilities of the frontline forest staffs are patrolling, monitoring, survey and conservation of wildlife in the park. They are also involved in periodic census taking of wildlife, helping researchers in field works and also have to escort and act as guides for the tourists. Besides that they have to maintain public relations and help in the socio economic development of the fringe area community. Thus they have multiple roles to play which however is not defined in their job profile as forest workers. 
Most workers do not put least preference to conservation and survey work.Their self efficacy questionnaire also reflects that they do not have any confidence on these areas nor the knowledge to carry out these duties. The aids and weapons provided to perform their duties are out dated; so often they are not confident to chase poachers. GPS patrolling has come in recently, however no scheduled training is provided to use weapons or in regard to their duties. The juniors often learn about their work from the seniors including how to use the weapons.

Communication with their superiors is rigid and the process of communication is more top to bottom and directive in nature. Till date there are more casual workers with minimum training working in the national park. This has also affected their sense of belongingness or to plan their future. This has also made them feel insecure about their future, as they have families to look after.No medical benefits are provided to them, nor are compensation provided for medical emergencies. This causes disruption in their work schedule as well as lowers their quality of life.Physical health of the staff is average to poor which was also reflected in the GHQ. Most of them did admit to intake of alcohol stating that it helps in releasing weariness and tiredness of the days work. Most workers expressed not having job satisfaction and are doing the job as they have nowhere to go.

Interestingly, the General Health Questionnaire (GHQ) which was designed to detect any psychological stress and correlates negatively with global quality of life reflected only 7 out of 82 suffering from psychological distress. This shows that the majority of the population's emotional health is average and they have been able to cope with the stress of the job and the living condition. This is contradictory to the report of the focus group discussion where the respondents have expressed that there are stresses of daily living and feeling low and depressed.

They have also expressed their concern about physical and emotional security. Moreover, they do not have any outlet to release stress as there is no facility for outdoor or indoor constructive recreation. Most of them were observed playing carom or cards in their rooms. Thus the tendency to consume alcohol or any substance abuse is higher after work is over. Most mentioned that what keeps in the job is their love for animals and the forest.

This can be related to resilience and coping skills they may have developed due to the long duration of their tenure in a stressful environment, thereby leading to numbness of feelings \& emotions. Any sign of emotional weakness may reflect poorly on their profession and job. Again, the poor reporting may be due to the lack of experience on the part of the data collectors in collecting data and documenting psychological responses. This may be so as the General Health Questionnaire (GHQ) is slightly complex to explain and as the data collectors were field personnel of Aaranyak who did not much experience in this area of work. The other possibility may be the understanding of the forest workers of the statements, as their highest educational levels was high school pass. Thus on retrospect it is felt that a different questionnaire may have been more effective. However enough data on the mental and emotional health of the forest workers were gathered from the focus group discussion.

Family support was poor, as the forest workers are not allowed to bring their families as it may be a danger to them. There is no fixed schedule for them to visit their families. Telephonic communication is also very poor. This has caused a sense of insecurity which is also reflected in the GHQ as well as in the self-efficacy questionnaire. Most shared that they feel depressed and lonely as they do not have much communication with the outside world. 
Self-efficacy questionnaire was designed keeping in mind the objective to understand the forest workers self-efficacy towards their work. Self-efficacy is a person's belief in his or her ability to succeed in a particular situation. Bandura described these beliefs as determinants of how people think, behave and feel. Moods, emotional states, physical reactions and stress level can all impact how a person feels about their personal abilities in a particular situation. This is a pivotal component of social cognitive theory in that beliefs of personal efficacy determine the acquisition of knowledge on which skills are founded. Thus by learning how to minimize stress and elevate mood when facing difficult or challenging tasks, people can improve their sense of self efficacy. Most forest workers felt that they were more confident in monitoring and patrolling activities in comparison to survey and conservation activities. Some of the areas of job analysis which they have scored low are listed below. Though the senior officers expressed these activities were important elements of their job profile, the forest guards did not think of them to be of priority in the jobs. Enhancing the self efficacy of the workers will enable them to minimize stress and elevate mood when facing difficult or challenging tasks. This can be done by providing adequate training in their job responsibilities and their seniors appreciating them when they conduct their job effectively and efficiently.

Overall it can be said that the forest workers are committed to their jobs. They would be able to be more effective and efficient in their jobs provided that intensive on the job training is given on a regular basis, necessary updated equipment reach the campsites on time, weapons are modernized and their living conditions are improved with minimum recreational facilities provided.

\section{Limitations of the survey}

- The usual challenges of mobilization were faced. The data collectors could collect the data only during off duty time

- $\quad$ The data was collected by the field personnel of Aaranyak and some of them were not very equipped to collect information on the GHQ inspite of training imparted to them on all the formats.

- Moreover data collection works were interrupted by the open season of the sanctuary when tourism peaks and the forest workers have to be available in their respective areas to man their multifarious responsibilities. Thus the off season period of the sanctuary was the only feasible time frame selected when the forest workers had more time to interact with the data collectors. Thus there was delay in data collection which pushed the project beyond the stipulated time period.

\section{Recommendations}

- Induction training to acquaint them to the job profile

- Equal treatment of permanent \& casual workers in regard to other facilities like uniform weapons etc. this will help in enhancement of the self respect and dignity.

- $\quad$ Capacity building on monitoring, conservation and survey

- $\quad$ Provision of uniform, ancillary equipment like raincoat torch GPS etc to be provided on time and given to both permanent \& casual workers

- $\quad$ Provision for games and other sport activities during their off duty hours

- $\quad$ Scheduled breaks for forest workers to meet their families 
- Improve living conditions like providing with gas connection, water filter, fencing around the camps to ward of wild animals.

- $\quad$ Provision to periodically have family get together and allowing the workers to meet their families may be scheduled

- Provision to periodically organize cultural events so that they so as to reduce alienation from the outside world

- To have workshops for workers reaching superannuation so that they can prepare themselves for quality of life after retirement

\section{Conclusion:}

In conclusion it can be said that the forest workers of Manas National Park have been able to carry on their duties inspite of all the issues of safety and security from wild animals and poachers. Their GHQ and self-efficacy results showed that their quality of life is adequate even though it was reflected otherwise in the FGD where they have stated that they do feel stress, feels lonely without the family and worry about their physical and mental health. This may be so as most of the respondents have been in the same job and in the same sanctuary from the time they have started their service life. So a sense of complacency and resignation to faith may have taken place. This also reflects on their lack of motivation to go the extra mile to be look after the sanctuary and protect it from poachers or learn new technologies to protect the park. The news on capturing are still on even after we had taken the survey.

The organisation Aaranyak has been a great source of support to the forest workers in regard to teaching them new techniques of camera trapping of animals, census of animals and to bring the surrounding community closer to the forest workers. Aaranyak with the support of the senior forest officials can provide periodic training to the forest workers on aspects of conservation; survey and monitoring of wildlife in the park thereby improve the quality of life of the forest workers. This will help to enhance their personnel effectiveness, leading to professional excellence. .

\section{INTRODUCTION}

Manas National Park is an UNESCO Natural World Heritage site and a Project Tiger reserve, an elephant reserve and a biosphere reserve in Assam, India. Located in the foothills of the Himalayas, it is contiguous with the Royal Manas National Park in Bhutan. The park is known for its rare endangered and endemic wildlife such as the Assam roofed turtle, hispid hare, golden langur and pygmy hog. Manas is also famous for its population of the wild water buffalo.

Presently, Aaranyak is implementing working on a project viz. The Manas Tiger Conservation Programme (MTCP). It is led by Aaranyak and being implemented in partnership with the Forest Department BTC, Wildlife Conservation Trust, Panthera and Awely. The project has been supported by International Union for Conservation of Nature (IUCN). The Goal of the Project is to achieve 50\% increase in tiger population in the next 10 years with enhanced protection measures, research and working on livelihood on the fringe area communities of MNP.

More than 300 forest personnel are engaged in the 500 sq.km.area of the park, spreading over 60 Camps to protect the rich flora and fauna of this World Heritage Site. The main role \& responsibilities 
of these official forest staff include protection\& monitoring of wildlife in the park. They are also supposed to maintain public relations with the fringe area community, involve in periodic census of wildlife, help researchers in field works and also escort and guide tourists as and when necessary.

These frontline forest personnel work in a very challenging environment with almost $24 \times 7$ work routines, detached from family and society for long periods with scant contact with the external world. Moreover, the threat of attack from wild animals, skirmishes with poachers as well as fringe area communities, lack of any form of entertainment or recreation facilities and the sheer monotony in the nature of work causes enormous physical \& mental strains on their lives. What amplifies the stress is that many of these personnel are not fully aware about their roles and responsibilities. Moreover, the expected emphatic response as guardians of the environment and ecology is something they have yet to internalize.

\section{RATIONALE}

In this backdrop, both the organizations agreed to partner for a survey on various aspects of the working environment of the frontline staff of the MNP. The scope of the survey is to understand the knowledge, skills and attitude of the target group in relation to their work place environment and job responsibilities. The objective is to assess their needs and quality of life in so far as conditions prevalent within the camps and the community in the fringe areas are concerned. The data collected will enable the framing of appropriate measures to enhance holistic growth and efficiency in the functioning of the frontline staff and better protection of MNP.

\section{GEOGRAPHICAL COVERAGE}

The project covered 500 sq. $\mathrm{km}$ area of the park where more than 300 forest personnel are engaged spreading over 60 Camps to protect the rich flora and fauna of this World Heritage Site.

\section{OBJECTIVES OF THE PROJECT}

- To understand the quality of life in so far as conditions prevalent within the camps and the community in the fringe areas are concerned

- $\quad$ To understand the gap in knowledge, skills and attitude of the forest workers in relation to their work place environment and job responsibilities

\section{TARGET GROUP}

The survey included frontline forest personnel working in Manas Wildlife Sanctuary, Government of Assam 


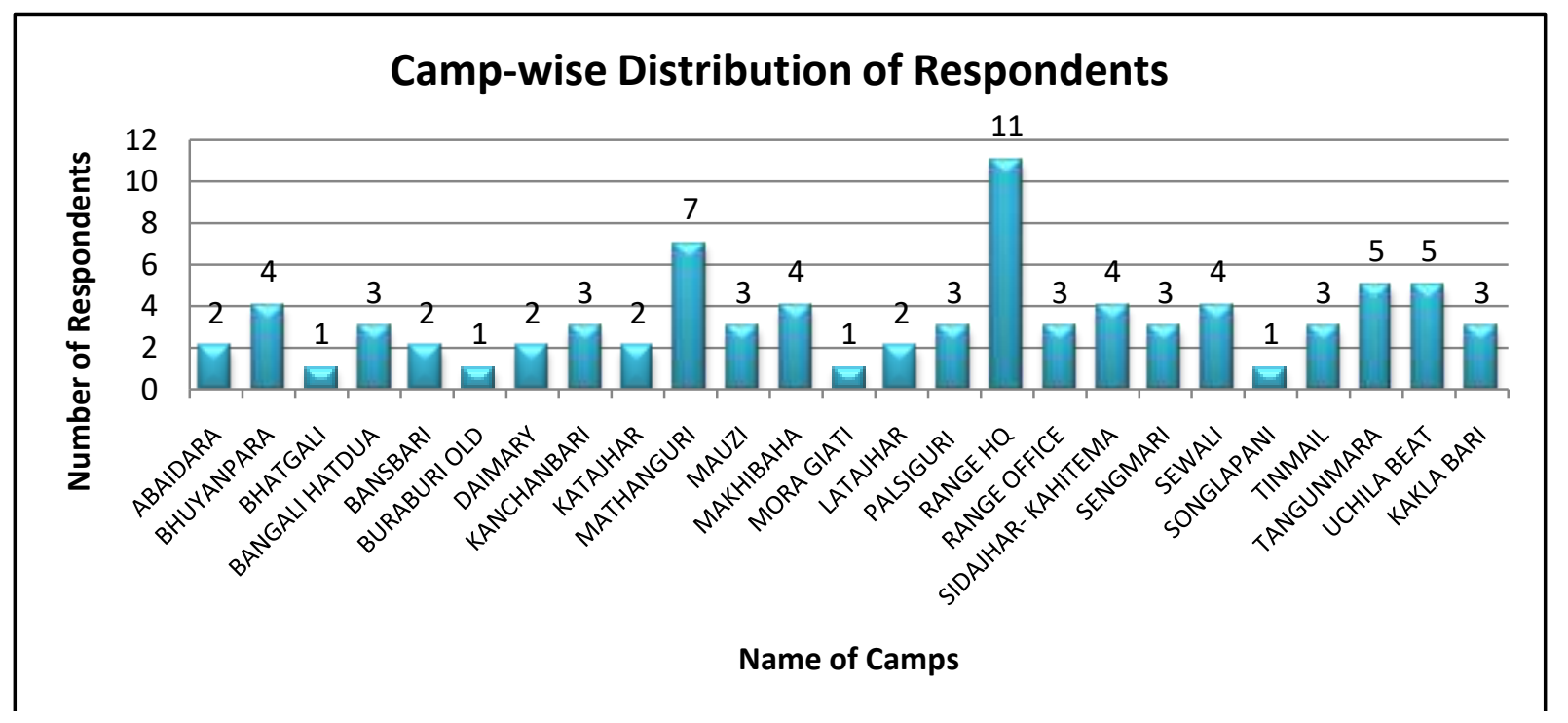

Figure 1:Camp-wise Distribution of Respondents ( $\mathrm{N}=82)$

\section{ROLE OF THE TWO ORGANISATIONS}

\section{Role of Aaranyak:}

- $\quad$ To provide necessary information required to carry out the survey

- To select manpowerfor data collection

- To coordinate with MIND India for training of manpower on the survey

- Collection of data from field and submission to MIND India for further action

- $\quad$ Timely release of funds

\section{Role of MIND India:}

- Development of Survey Format/FGD Schedule/ Allied Documentation for the survey

- $\quad$ Field testing of formats

- Training of Manpower for conduction of the survey

- $\quad$ Data Entry, Collation, Analysis

- $\quad$ Report Generation

\section{METHODOLOGY}

\section{Phase I: Development and Adaptation of Tools}

Focus group discussion was held with the aim to form a repertoire of perceptions, ideas, opinions and beliefs expressed by the group on their way of life and the socio-cultural milieu they hail from, their quality of life, as well as their expectations in regard to the kind training they require to be effective in their job.

\section{Tools developed and adapted were:}


- Demographic Profiling of Frontline Forest Personnel of Manas National Park

- $\quad$ Questionnaire for Job Analysis of Frontline Forest Personnel

- Questionnaire on Self-efficacy of Frontline Forest Personnel

- $\quad$ Adaptation of General Health Questionnaire (GHQ) a standardized tool adapted to field needs

\section{Phase II: Implementation of the Tools}

Objective 1:To understand the quality of life in so far as conditions prevalent within the camps and the community in the fringe areas are concerned

\section{Tools used:}

- $\quad$ Focus group discussion

- Demographic Profiling of Frontline Forest Personnel of Manas National Park

- $\quad$ General Health Questionnaire (GHQ)

Objective 2: To understand the gap in knowledge, skills and attitude of the target group in relation to their work place environment and job responsibilities

\section{Tools used:}

- Questionnaire for Job Analysis of front line forest personnel

- Questionnaire on Self-Efficacy of front line forest personnel

\section{ACTIVITIES}

\section{ACTIVITY 1: Conduction of focus group discussion (FGD)}

Focus group discussion was held with the aim to form a repertoire of perceptions, ideas, opinions and beliefs expressed by the group on their way of life and the socio-cultural milieu they hail from, their quality of life, as well as their expectations in regard to the kind training they require to be effective in their job. The discussion was recorded digitally and transcript.

\section{Methodology:}

A checklist with relevant questions was developed based on source of secondary data and field experience. The discussion was recorded digitally and transcribed. The data was collated and qualitatively analysed using content analysis.

\section{Selection of Sample:}

Personnel from 10 camps were gathered in two camp sites. $75 \%$ of the forest personnel were staying towards the middle of the forest and $25 \%$ were staying in the fringe areas of the park, close to the community. 


\section{Conduction of the Focus Group Discussion:}

- The questions for each of the thematic areas were translated into the vernacular, i.e., Assamese.

- The discussion took place after permission was sought from the in charge of the forest department.

- $\quad$ Prior to the discussion, it was verbally stated that the information gathered will be used for research purpose only. On their acceptance the discussion started.

- $\quad$ Permission was sought from the groups to video record the discussions.

- $\quad$ The discussions were digitally video recorded.

- $\quad$ The audio tracks were transcribed.

- $\quad$ The responses under each thematic area was analysed .

- Observations and comments of the facilitators were recorded within each thematic area

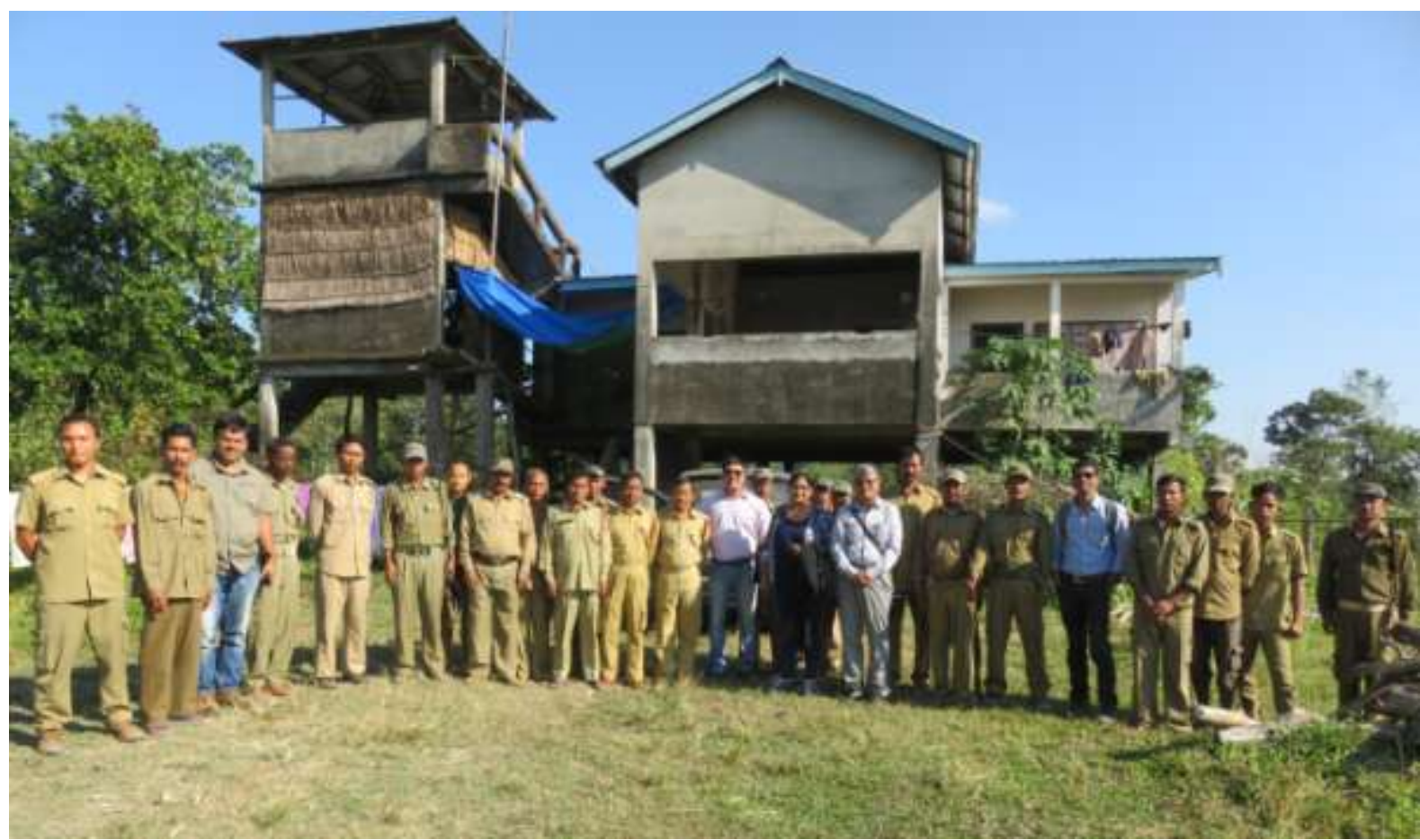




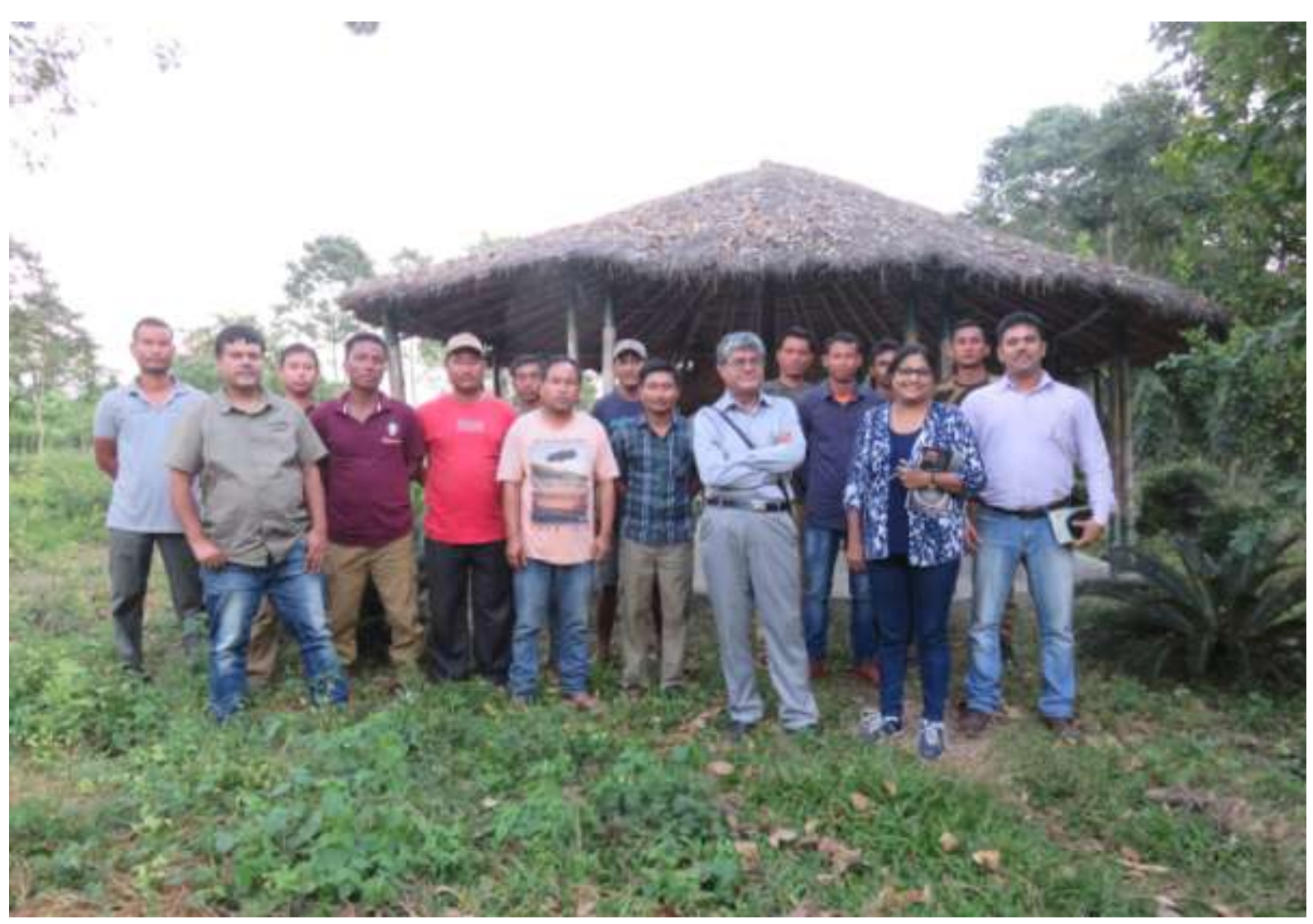

Figure 2: Forest personnel, members of Aaranyak, MIND India team gather for the FGD

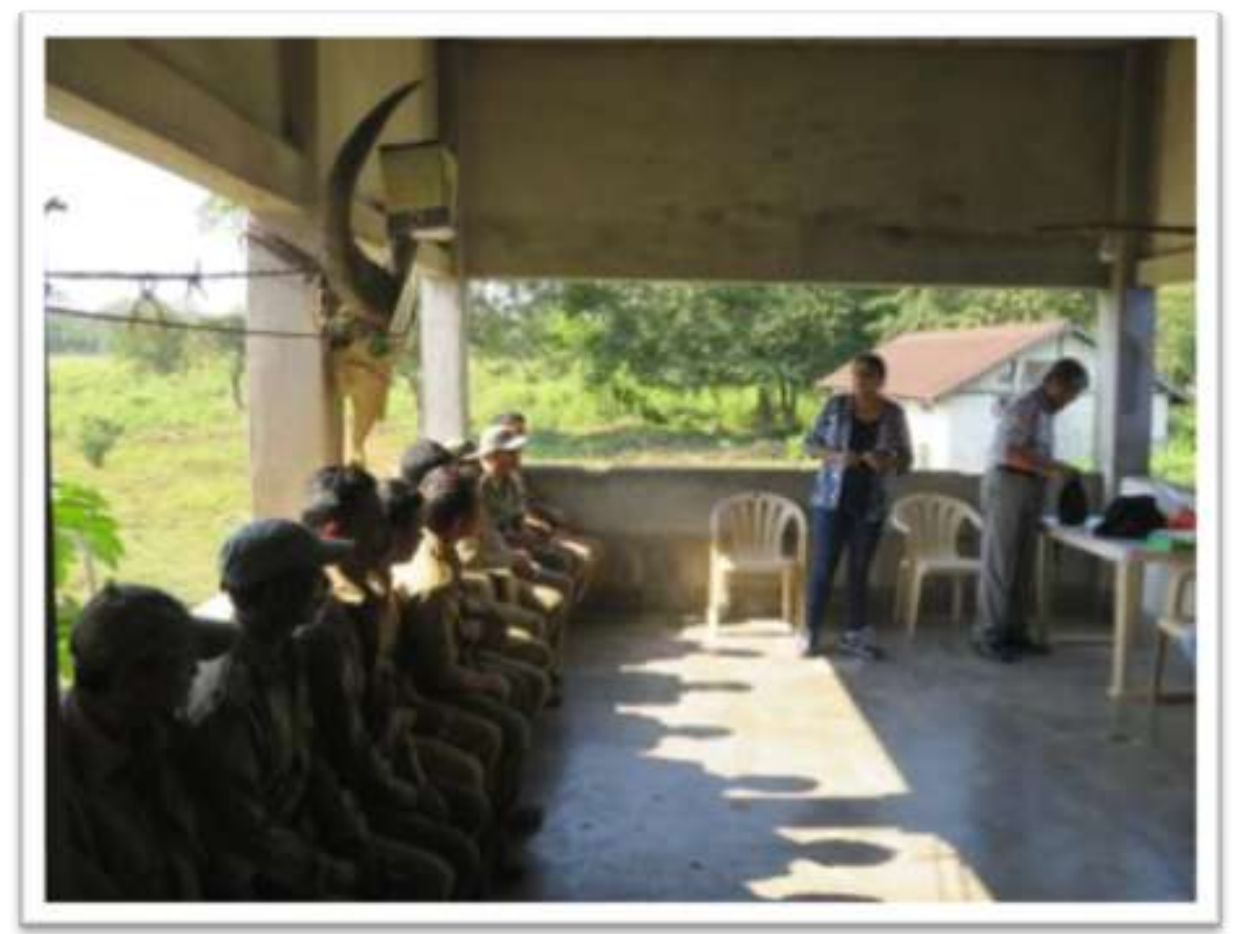

Figure 3: Focus Group Discussion underway in one of the camps in Manas National Park 


\section{FINDINGS OF THE FOCUS GROUP DISCUSSION}

Age Wise Distribution:Respondents were between the age range of 20 years to 50 and above years

Years of Service: Most of the respondents had a minimum one year of service to maximum 28 years of service

Job Description:The main role \& responsibilities of the frontline forest staffs are protection \& monitoring of wildlife in the park. They are also involved in periodic census of wildlife, help the researchers in field works, and also escort and guide the tourists. Besides that they have to maintain public relations and help in the socio economic development of the fringe area community.

The format of the Demographic Profile is annexed hereto and marked as Annexure 1

Qualitative Data: The discussion was based on the checklist framed whereby certain core areas were selected for better understanding and clarity of issues and concerns

\section{Activities carried out by forest personnel:}

- $\quad$ Patrolling

- $\quad$ Animal census

- $\quad$ Monitoring of wild animals

- $\quad$ Act as tourist guide

- $\quad$ Support the neighboring community

- $\quad$ Support the veterinary team

- $\quad$ Help research team

- $\quad$ Maintain and monitor the boundary

- $\quad$ Maintain positive relationship with neighboring country namely Bhutan

Aids to perform their duties:

- Weapons are provided but are out dated. So most often they shy away from chasing poachers

- $\quad$ GPS patrolling has come in recently

- $\quad$ No training is provided to use weapons or on their duties.

- There is no in service training. There is only one induction training. The juniors often learn from their seniors including how to use the weapons.

- Communication with their superiors is very rigid and more top to bottom communication process

- There is no fixed schedule for their duty or to take holidays. Most of them have an internal arrangement of taking leave 
- $\quad$ Promotion system is not in place. Nor there is a system of regular shifting of forest staff from one park to another.

- $\quad$ Salary is low compared to the national wage level. TA is not fixed

- $\quad$ Most of the forest personnel are not permanent workers.

- No medical benefits are provided to them. In case there is an accident or someone is unwell, they have to travel a long distance by foot or by government vehicle which is not often available

- No compensation is provided for medical emergencies

- Uniforms, Rain coats, boots, torch and other such equipment are not received on time. This causes a lots of disruption in their work schedule as well as lowers down their quality of life

- Most of the forest personnel have to appear in court to identify the poachers or similar work for which they are not paid their travel allowances. Some of them have to travel long distances as they may have been transferred to different district altogether

\section{Living conditions in the camp sites:}

- $\quad$ Per camp there are minimum 5 people to maximum 16 people living together. It also depends on the camp size and the area that is covered.

- $\quad$ Minimum first aid is available in the camp sites

- $\quad$ Fresh drinking water is not available as water filters are not been provided. They have to boil water, cool it down and then use it as drinking water.

- $\quad$ Bathroom facility is poor and unhygienic

- A lot of time is spent on cooking and collecting wood as gas or other cooking amenities are not adequately provided.

- $\quad$ Proper fencing around the camp sites are not present and hence most of the times their rations and kitchen are attacked by wild animals

- Most of them did admit to intake of alcohol to release them of their day's weary and tiredness

\section{Community Support:}

- There is no community support system or contact with the greater community.

- The personnel are not allowed to bring their families as it may be a danger to them, whereas there is no fixed schedule for them to visit their families.

- Telephonic communication is very poor

- No facility for recreation is provided especially outdoor activities like volley ball, football etc. Most of them were seen playing carom or cards in their rooms.

- Most shared that they feel depressed and lonely as they do not have much communication with the outside world

Training Requirements: 
All personnel agreed on training requirements in the following areas:

- To have on the job training for all forest personnel including the causal, temporary workers

- To have training on use of different weapons

- To have training for physical fitness

- To train on tourism activities and knowledge as most of the time they have to act as tourist guide

- $\quad$ Training on legal areas related to wildlife and maintaining the park is required.

The questions framed for the Focus Group Discussion are annexed hereto and marked as Annexure 2

\section{ACTIVITY 2: Development of Training Tools}

- Demographic Profiling of Frontline Forest Personnel of Manas National Park

- Questionnaire for Job Analysis of Frontline Forest Personnel

- Questionnaire on self-efficacy of Frontline Forest Personnel

- $\quad$ General Health Questionnaire (GHQ) a standardized tool adapted to field needs.

The General Health Questionnaire (GHQ), an available standardized tool was adapted. Apart from that the rest of the training tools were developed by MIND India based on the Focus Group Discussion and secondary data gathered from Aaranyak.

The formats of the tools are annexed hereto and marked as Annexures $3,4 \& 5$

\section{ACTIVITY 3: Training of Manpower}

The selected personnel of Aaranyak were trained to administer the questionnaire in the field to collect appropriate data.

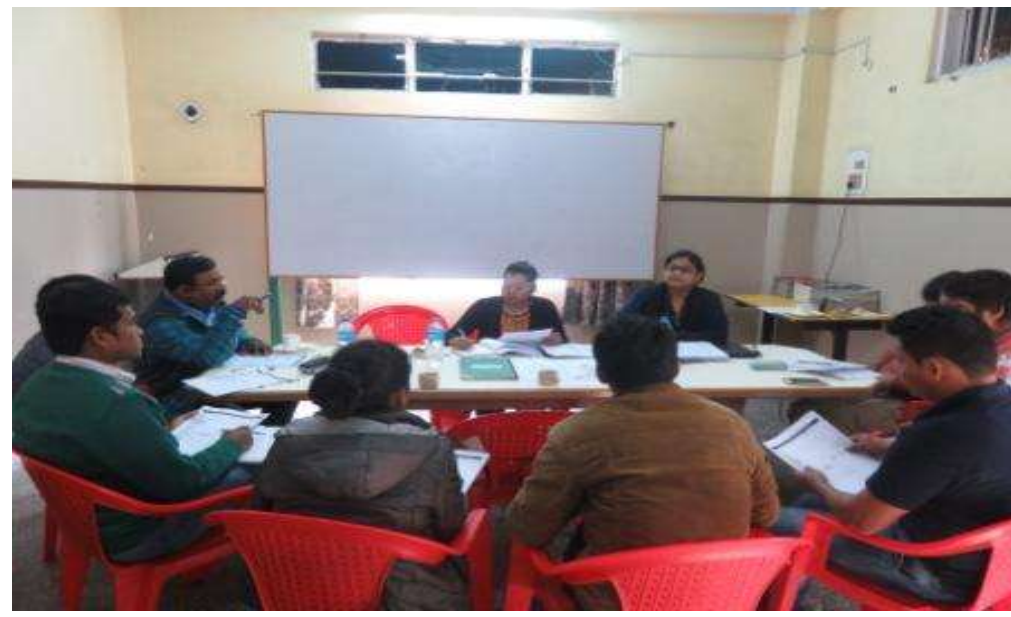

Figure 4: Training of Aaranyak team members on administration of field tools by Dr. Sangeeta Goswami 


\section{ACTIVITY 4: Handholding of Aaranyak Personnel for Data Collection}

Handholding of the Aaranyak team members was undertaken to facilitate the process of the survey as the concept of quality of life was new for the group. The MIND India team supported the data collectorsto check and assist understanding of the Aaranyak team on the method of data collection.
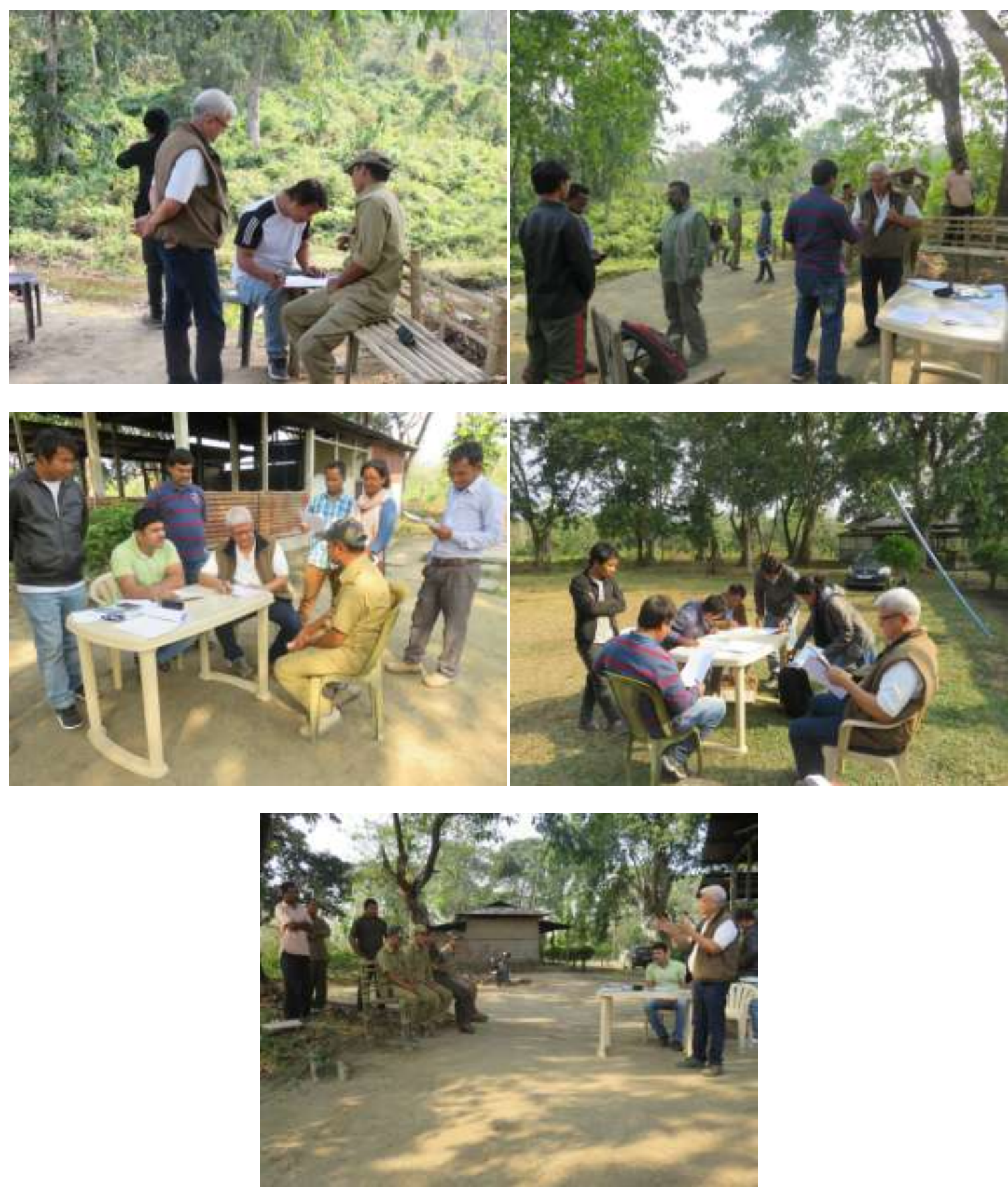

Figure 5: MIND India members handholding Aaranyak Team during Data Collection

\section{DATA COLLECTION}

Purposive sampling was used to select the forest workers. Purposive sampling is a nonprobability sampling technique in which researcher relies on his/her judgment when choosing 
members of population to participate in the study. Researchers often believe that they can obtain a representative sample by using a sound judgment and experience. Forest workers present in the camps during the time of data collection were approached for the project. In total 82 forest workers were surveyed.
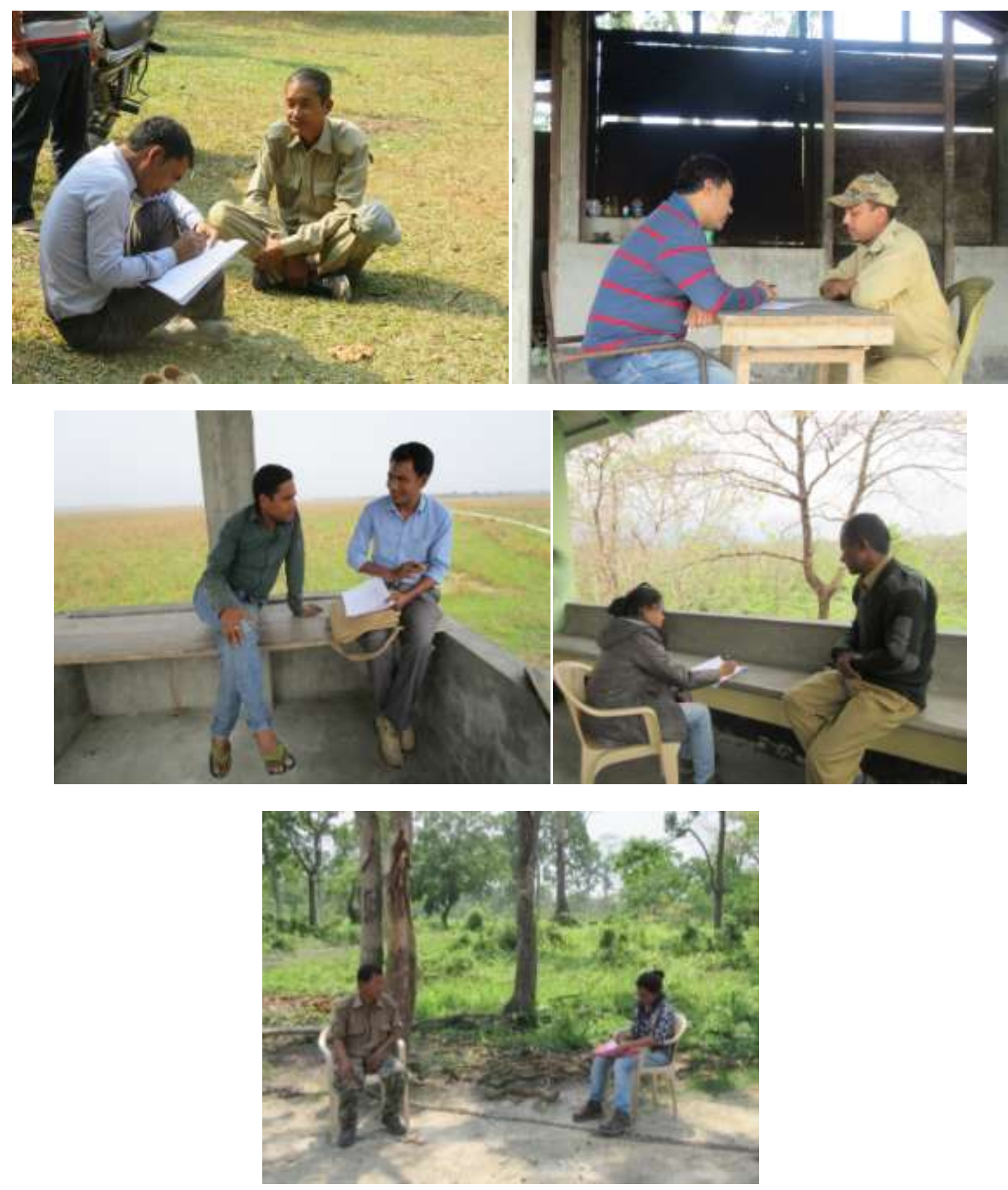

Figure 6: Data collection works underway

\section{METHOD OF ANALYSIS}

According to the World Health Organization (WHO), quality of life is defined as "the individual's perception of their position in life in the context of the culture and value systems in which they live and in relation to their goals." Quality of life (QOL) is the general well-being of individuals and 
societies, outlining negative and positive features of life. It observes life satisfaction, including everything from physical health, family, education, employment, wealth, religious beliefs, finance and the environment. Standard indicators of the quality of life include not only wealth and employment but also the built environment, physical and mental health, education, recreation and leisure time, and social belonging.

Keeping this premise in mind, the data was collated and analyzed. Content analysis was conducted for the Focused Group Discussion. SPSS was used for job analysis, self-efficacy and General Health Questionnaire (GHQ) to collate the quantitative data.

\section{RESULTS}

\section{DEMOGRAPHIC PROFILE:}

The data was collected from two ranges namely Bhuyanpara and Bansbari of which 38 respondents were from Bhuyanpara and 44 from Bansbari. Total sample size was 82 respondents

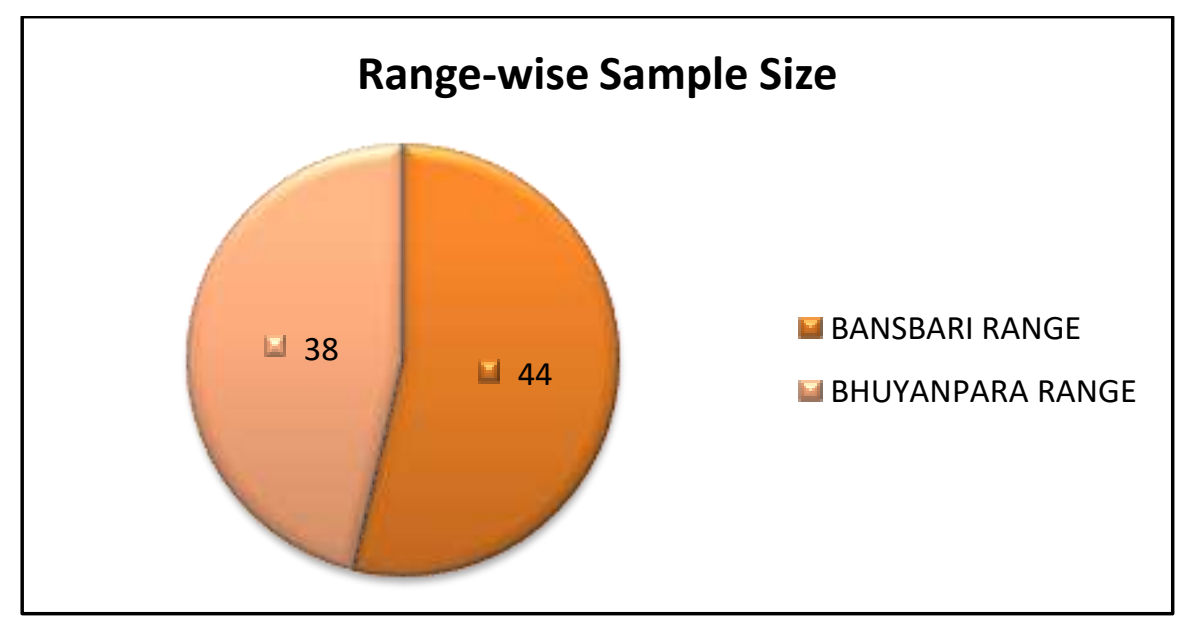

Figure 7: Sample size from Bansbari and Bhuyanpara Ranges

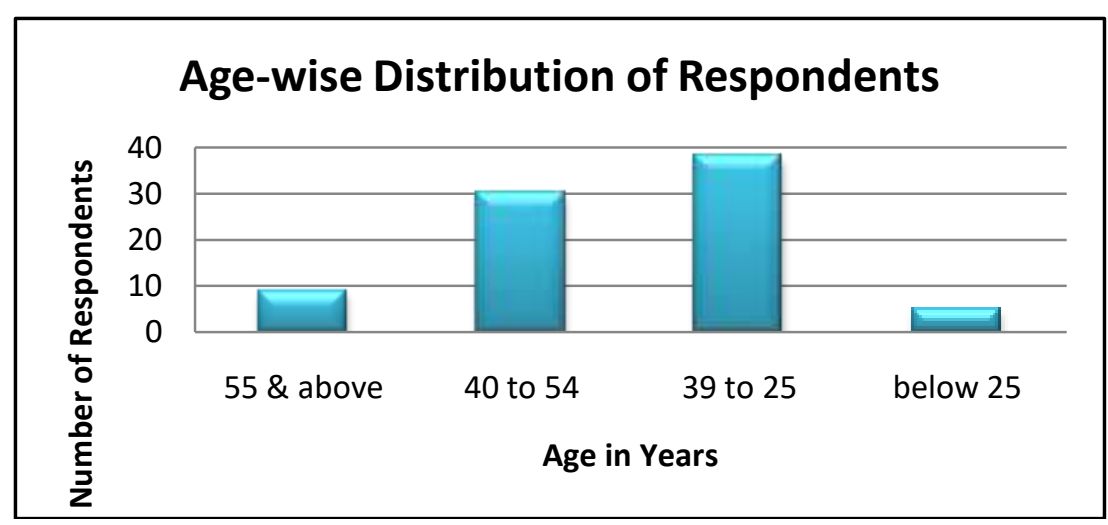

Figure 8:Age of Respondents from both ranges 
The age of the respondents ranged from 19 years to 55 and above. Out of 82 personnel, 5 were the youngest in the group in the age range of 25years and below, 68 were in the age range of 30 to 38 years while 9 were 55 and above. All respondents were male.

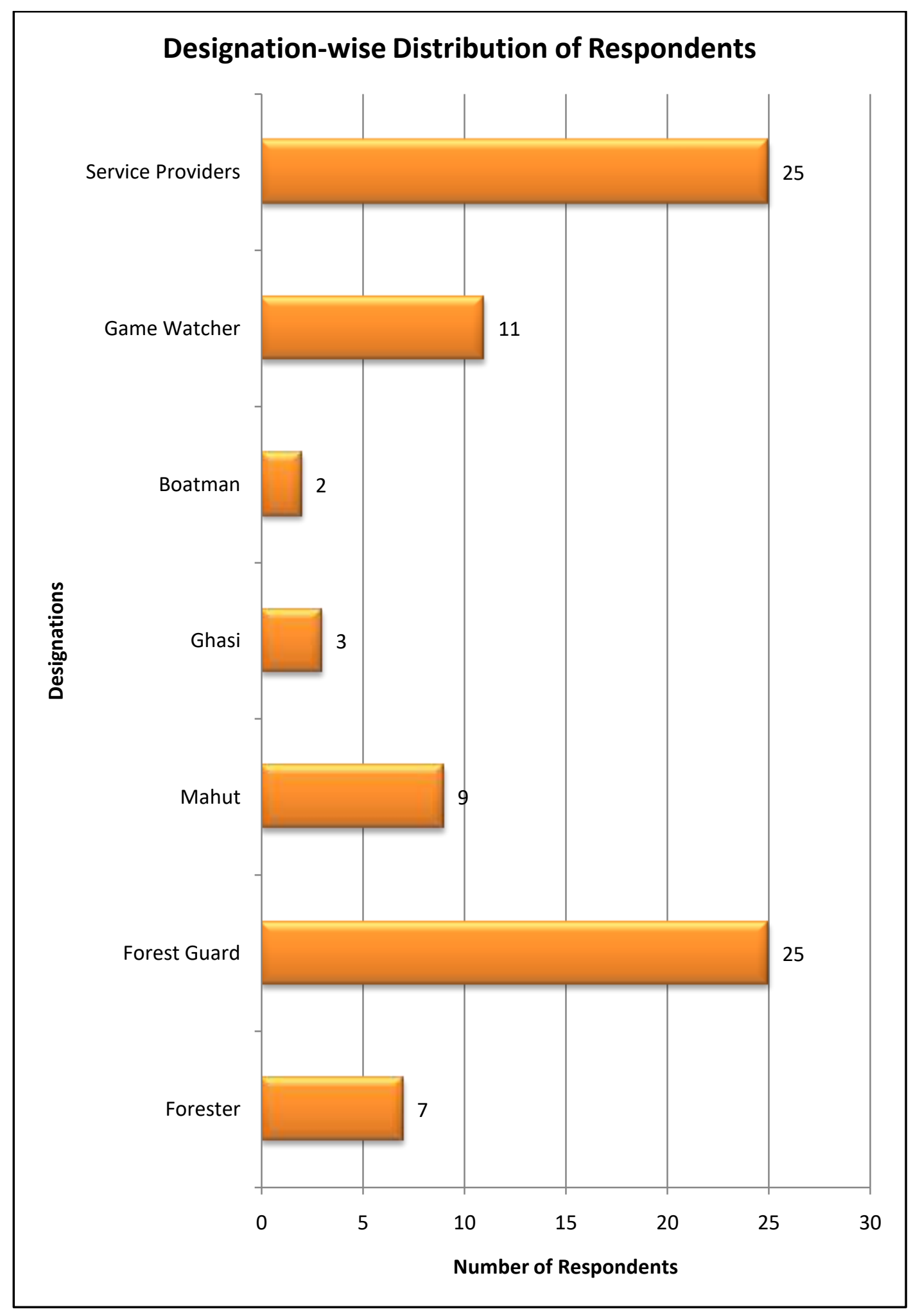

Figure 9: Designation of Respondents 
As seen from the figure above(25)respondentsare forest guards, game watchers were (11) in number, followed by forester(7), mahut (9), Ghasi (3), Boatman (2). The other workers were 25 in numberwhich included driver, animal keeper, waterman, generator operator, cook, and other causal workers clubbed together as service providers.

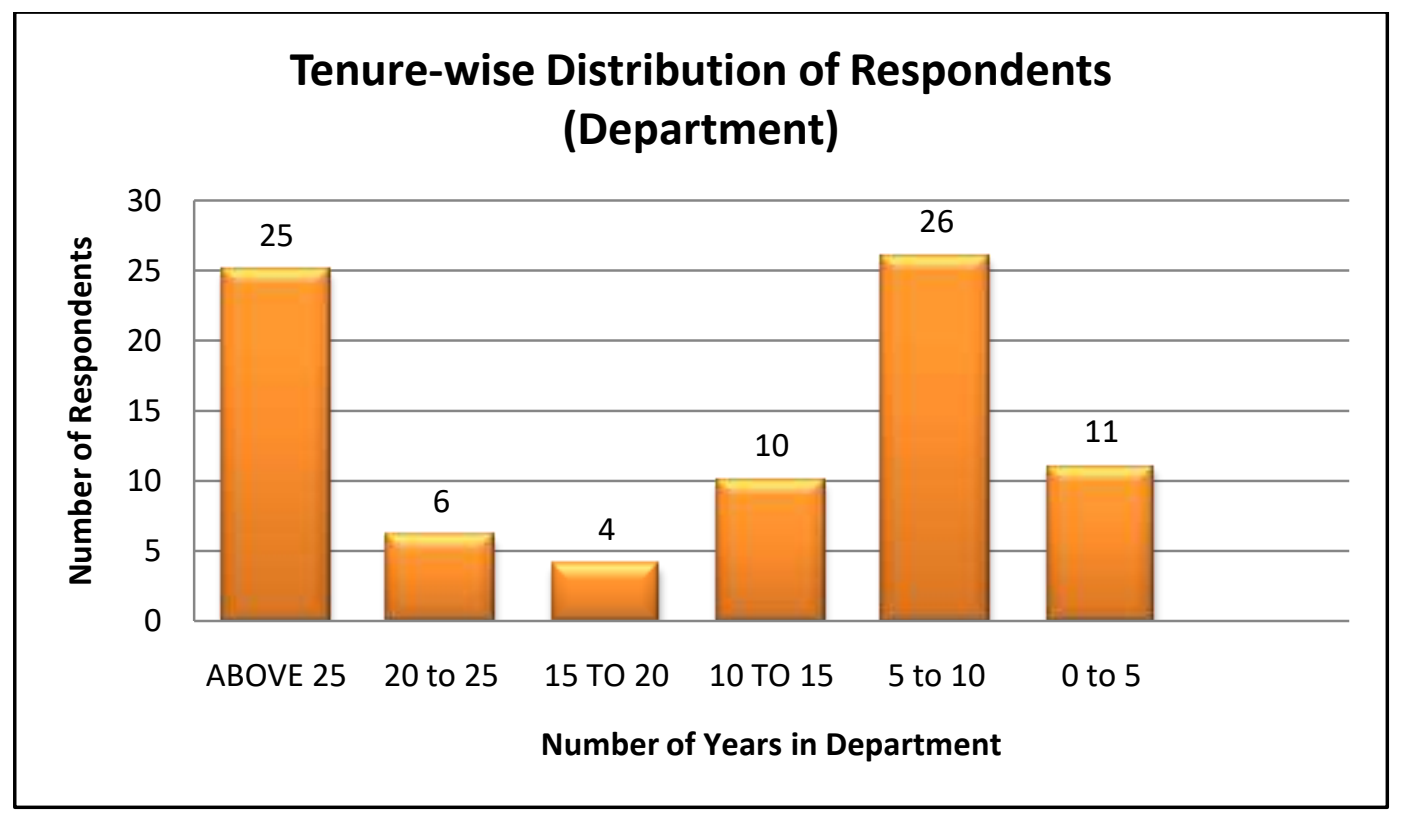

Figure 10: Tenure of Service of the Respondents in the Department

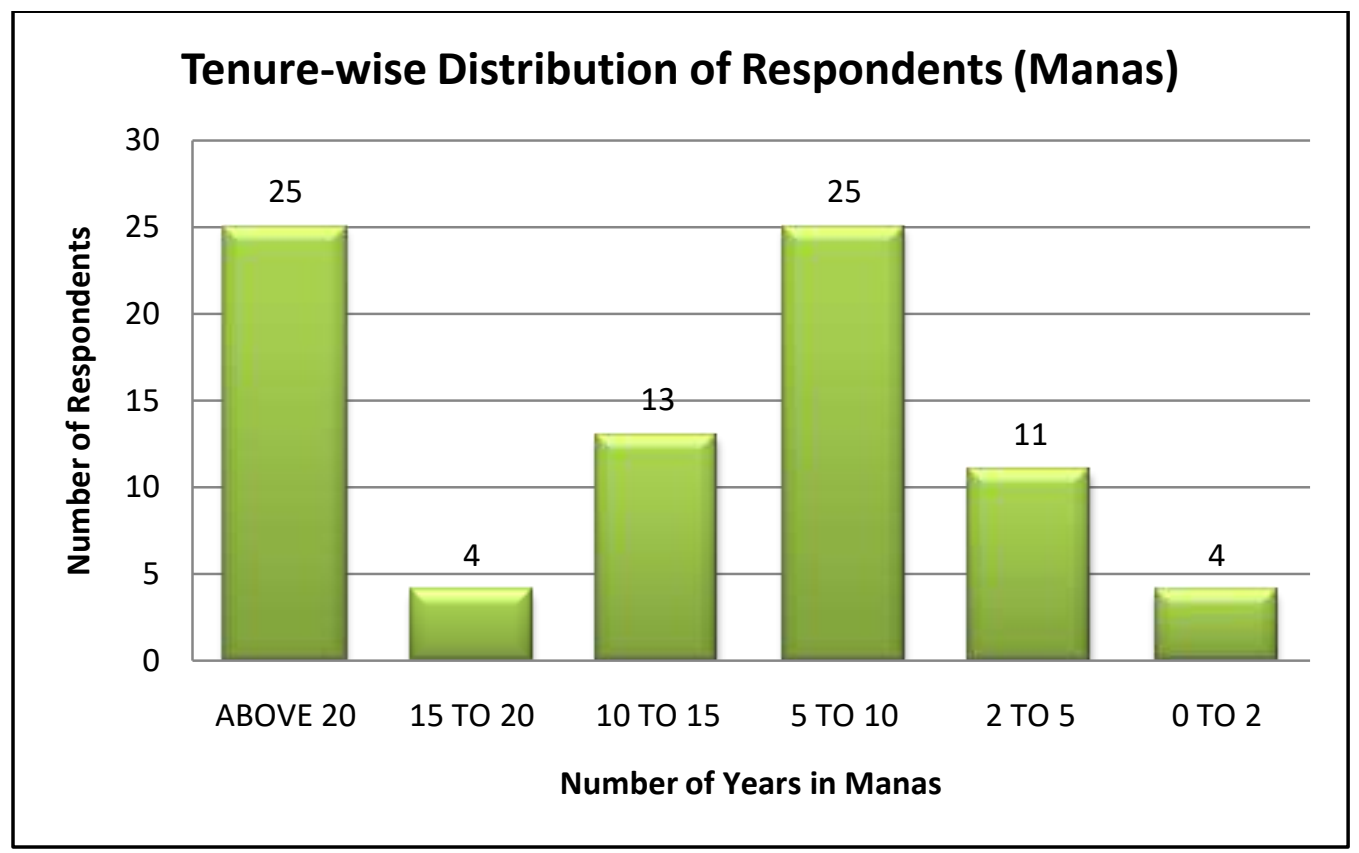

Figure 11: Tenure of service of the respondents in Manas National Park

As figures 9 and 10 above, reflects most respondents have completed 20 years and above service in the department and in Manas National Park (MNP). This also correlates with their statement in FGD as not getting a transfer from one sanctuary to another. The next group in the service range of 5 to 10 
years which has the age range of 30 to 38 years of younger forest workers. The maximum service tenure observed is 28 years in the department as well as in MNP and the minimum service tenure is five years in the department and two years in MNP.

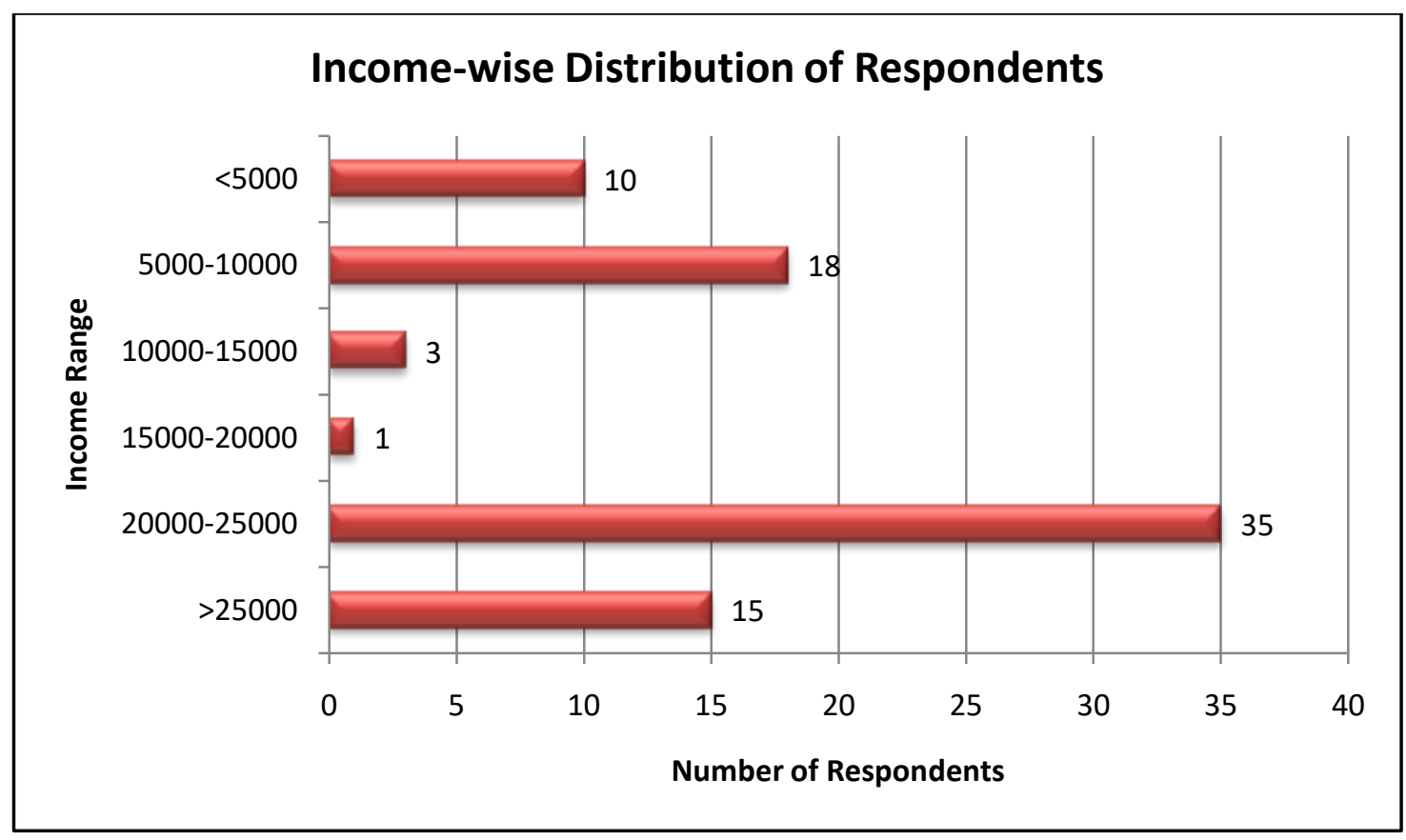

Figure 12: Monthly income range of the Respondents

The minimum income of the forest workers is Rs 5000/- to maximum of above Rs 25,000/-. Of that 35 respondent are in the range of Rs 20000/- to 25000/- income per month. The other service providers which is comparatively a larger group receives Rs 5000/- to 10,000/- on a monthly basis.

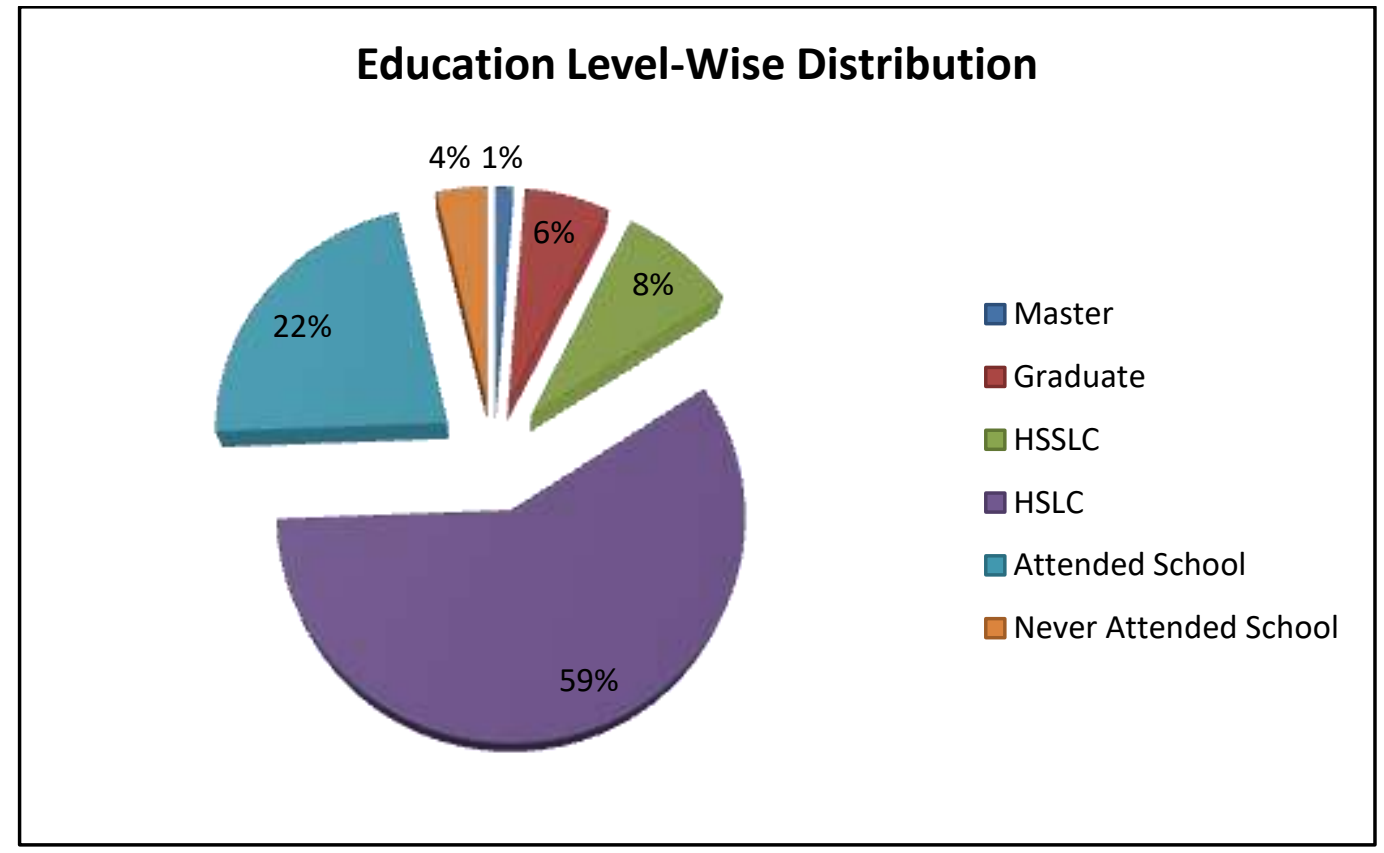

Figure 13: Level of education of the Respondents 
As seen from the figure above, $59 \%$ are High school pass, followed by $22 \%$ who have only attended school. Out of 82 respondents, only $6 \%$ havecompleted graduation and there was only one person who has a master degree.

In regard to community that the respondents belong to, 75 out of 82respondents were Hindu and most of them were from the Scheduled Castes (48) and Other Backward Caste (21).

Marital status of the 82 respondents , $89 \%$ are married having dependents of 4 to 8 members which includes wife, children, parents, relatives and grandchildren.

Looking at the work life demographics, 65 reported of not getting any promotion during their term of working in Manas National Park. Promotions are limited to change in designation while salary may increase or may not along with it. Most of the promotion was related to their position becoming permanent from casual. This was also reflected during the focused group discussion. Some of them neared their retirement age without any promotion during their entire tenure as forest workers. Only a few have received awards for bravery or for good performance from the government or from NGOs. Some of the recognition are certificate from NGO for catching pig hog, got medal from some Delhi party for performance during duty, certificate for working with dedication, recognition for capturing poachers, award for dedication known as "Maosawm Hanja Bantha".

\section{FINDINGS OF THE FOCUS GROUP DISCUSSION}

The main role $\&$ responsibilities of the frontline forest staffs are protection $\&$ monitoring of wildlife in the park. They are also involved in periodic census of wildlife, helping researchers in field works, and also escorting and guiding the tourists. Besides that they have to maintain public relations and help in the socio-economic development of the fringe area community.

The core activities carried out by forest personnel:

- Patrolling

- Animal census

- Monitoring of wild animals

- Act as tourist guide

- Support the neighboring community

- Support the veterinary team

- Help research team

- Maintain and monitor the boundary

- Maintain positive relationship with neighboring country namely Bhutan

- Based on the Content Analysis of the FGD, below are some key areas of intervention that can be taken up for the forest workers in the park

- To have increased communication between the senior officers and the forest workers 
- To increase their sense of security in regard to their jobs by making most of them permanent.

- This will also help in increasing the motivation of the workers.

- To have on the job training for all forest personnel including the causal, temporary workers

- To have training on use of different weapons

- To have training for physical fitness

- To train on tourism activities and knowledge as most of the time they have to act as tourist guide

- Training on legal areas related to wildlife and maintaining the park is required.

- Effective use of IEC materials for different groups

- To provide training in Leadership and team building

\section{FINDINGS OF GENERAL HEALTH QUESTIONNAIRE (GHQ)}

The General Health Questionnaire (GHQ) is a measure of current mental health and has been extensively used in different settings and different cultures. It was designed to be a self-administered screening test aimed at detecting psychiatric disorders among respondents in community settings and non-psychiatric clinical settings. The questionnaire was designed to be easy to administer, and did not require the person administering it to make subjective assessments about the respondent. The General Health Questionnaire (GHQ) is a psychometric screening tool to identify mental health condition in general population samples. The questionnaire correlates negatively with global quality of life.

\begin{tabular}{|l|l|l|}
\hline TOTAL GHQ SCORE & FREQUENCY & PERCENTAGE \\
\hline 0 & 38 & $46 \%$ \\
\hline 1 & 14 & $17 \%$ \\
\hline 2 & 13 & $16 \%$ \\
\hline 3 & 6 & $7 \%$ \\
\hline 4 & 4 & $5 \%$ \\
\hline 5 & 2 & $2 \%$ \\
\hline 7 & 4 & $6 \%$ \\
\hline 8 & 1 & $1 \%$ \\
\hline Total & 82 & 100.0 \\
\hline
\end{tabular}

Table 1:Scores obtained in General Health Questionnaire (GHQ) N=82 


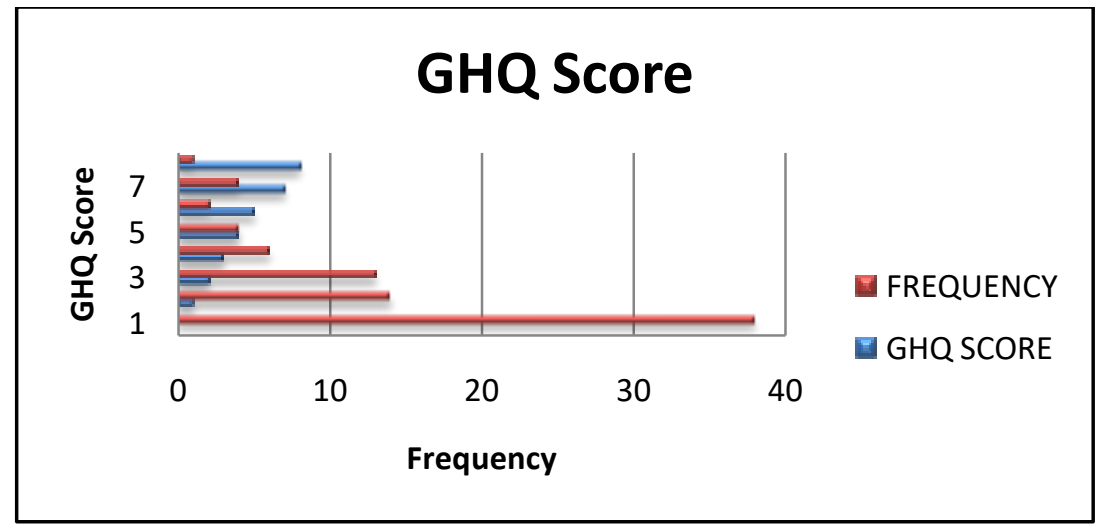

Figure 14: General Health Questionnaire Scores by Respondents

As seen from table 2 and figure 13 above, of the 82 respondents only 7 respondentsreported of suffering from psychological distress which is indicative by the GHQ cutoff score of above 5. This shows that the majority of the population reported of minimal or negative psychological distress during their functioning in Manas National park. However, during FGD, the respondents have expressed that there are stresses of daily living and feeling low and depressed. They have also expressed their concern about physical and emotional security. This can be related to resilience and coping skills they developed due to the long duration of their tenure in a stressful environment, thereby leading to numbness of feelings \& emotions.

\section{FINDINGS OF JOB ANALYSIS OF FOREST WORKERS}

Job analysis questionnaire was designed keeping in mind the objective of understanding the job profile and job responsibilities of the forest worker and how aware are they of it. There were in total five domains in the questionnaire, namely Patrolling, Monitoring, Survey, Conservation and Working conditions. In addition to this, an open ended question was asked on how they would like to improve their lives as forest workers, so as to understand their individual opinion and understanding of the job profile and situation that they are in.

As there is no specific job description of forest workers, initially one questionnaire was constructed to assess relative frequency of core job activities based upon observation, Focus Group Discussion\&semi interview. These activities are patrolling, monitoring, survey and conservation. Data were collected from Bhuyanpara and Bansbari ranges. Results revealed differential perception of forest workers in both ranges. Below is detailed description of core activities and working conditions.

\begin{tabular}{|l|l|l|}
\hline \multicolumn{1}{|c|}{ Domains } & \multicolumn{1}{|c|}{ Mean } & \multicolumn{1}{c|}{ SD } \\
\hline Patrolling & 2.67 & 0.28 \\
\hline Monitoring & 2.92 & 0.25 \\
\hline Survey & 1.97 & 0.22 \\
\hline Conservation & 1.43 & 0.24 \\
\hline
\end{tabular}

Table 2: Domain wise Job Analysis of Forest personnel (N=82) 
The results reveal that forest workers perceived monitoring activities as more important $(M=2.92$, $\mathrm{SD}=0.25)$ than patrolling $(\mathrm{M}=2.67, \mathrm{SD}=0.28)$. Results show that forest workers felt conservation as relatively less frequent activities in their job duties $(\mathrm{M}=1.43, \mathrm{SD}=0.24)$, so was survey activities $(\mathrm{M}=1.97, \mathrm{SD}=0.22)$. Working condition was assessed with 13 Yes-No type items. Results reveal that forest workers were deprived of the basic needs like getting drinking water, toilet $(\mathrm{M}=1.10, \mathrm{SD}=0.30)$, working without wireless communication( $\mathrm{M}=1.11, \mathrm{SD}=0.31)$.

\section{Patrolling:}

Patrolling is reflected as one of the most important duty of a forest worker. It includes controlling wild animals, maintaining forest safety, the environment, educating the public about the animals and forest safety by escorting officers and tourists.

The responses were analysed and their frequency and percentage were taken out.

Job analysis results reveal that patrolling job description includes knowing the typical habitats $(\mathrm{M}=3.61, \mathrm{SD}=0.85)$, protocol patrol duties $(\mathrm{M}=3.42, \mathrm{SD}=1.17)$, briefing and debriefing of patrol duties $(\mathrm{M}=3.31, \mathrm{SD}=1.45)$, submitting and maintaining of patrolling duties $(\mathrm{M}=3.22, \mathrm{SD}=1.69)$, counter attacking to aggressive animals $(\mathrm{M}=3.05, \mathrm{SD}=1.12)$.

\begin{tabular}{|l|l|l|}
\hline \multicolumn{1}{|c|}{ Items } & \multicolumn{1}{|c|}{ Mean } & \multicolumn{1}{c|}{ SD } \\
\hline Knowing the typical habitats & 3.61 & 0 \\
\hline Protocol patrol duties & 3.42 & 1.17 \\
\hline $\begin{array}{l}\text { Briefing and debriefing of } \\
\text { patrol duties }\end{array}$ & 3.31 & 1.45 \\
\hline $\begin{array}{l}\text { Submitting and maintaining of } \\
\text { patrolling duties }\end{array}$ & 3.22 & 1.69 \\
\hline $\begin{array}{l}\text { Counter attacking to aggressive } \\
\text { animals }\end{array}$ & 3.05 & 1.12 \\
\hline
\end{tabular}

Table 3: Items under patrolling domain under job analysis

Some of the items of patrolling where they have scored low are listed below. Though the senior officers expressed these activities were important elements of their job profile, the forest guards did not think of them to be of priority in the jobs.

- $\quad$ Counter attacking poachers

- Interrogation of poachers \& intruders

- $\quad$ Protecting animals from injury

- $\quad$ Taking accused (asami) to court

- $\quad$ Escorting officers and tourists 
Forest workers of Bhuyanpara felt that they performed more patrolling duty $(\mathrm{M}=2.91, \mathrm{SD}=0.34)$ than their counterparts $(\mathrm{M}=2.46, \mathrm{SD}=0.29)$.

\section{Monitoring:}

Regular monitoring is important for safety of the forest. Results reveal that forest workers perceived monitoring activities more important $(\mathrm{M}=2.92, \mathrm{SD}=0.25)$ than patrolling $(\mathrm{M}=2.67, \mathrm{SD}=0.28)$

\begin{tabular}{|l|c|c|}
\hline \multicolumn{1}{|c|}{ Items } & Mean & SD \\
\hline $\begin{array}{l}\text { Identifying pug marks of } \\
\text { animals }\end{array}$ & 3.64 & 0.86 \\
\hline Tracking movement of animals & 3.33 & 1.16 \\
\hline Monitoring animal movement & 3.18 & 1.28 \\
\hline
\end{tabular}

Like patrolling, forest workers of Bhuyanpara experienced more $(\mathrm{M}=3.16, \mathrm{SD}=0.35)$ monitoring activities than their counterparts $(\mathrm{M}=2.7, \mathrm{SD}=0.23)$. The monitoring activities included identifying pug marks of animals $(\mathrm{M}=3.64, \mathrm{SD}=0.86)$, tracking movement of animals $(\mathrm{M}=3.33, \mathrm{SD}=1.16)$, monitoring animal movement $(\mathrm{M}=3.18, \mathrm{SD}=1.28)$.

The items where they scored low were:

- $\quad$ Protection of workers \&labour involved in park infrastructure work

\section{Survey:}

\begin{tabular}{|l|l|l|}
\hline \multicolumn{1}{|c|}{ Items } & \multicolumn{1}{|c|}{ Mean } & \multicolumn{1}{c|}{ SD } \\
\hline $\begin{array}{l}\text { Helping researchers \& students } \\
\text { in survey activities }\end{array}$ & 2.38 & 1.52 \\
\hline $\begin{array}{l}\text { Mapping the routes of animal } \\
\text { movement }\end{array}$ & 1.43 & $1 . .64$ \\
\hline Counting animals for census & 2.59 & 1.13 \\
\hline
\end{tabular}

Table 4:Items under survey domain under job analysis

Forest workers less frequently performed survey activities $(\mathrm{M}=1.97, \mathrm{SD}=0.22)$. Like earlier, forest workers of Bhuyanpara $(\mathrm{M}=2.31, \mathrm{SD}=0.20)$ performed more survey activities than Bansbari $(\mathrm{M}=1.67$, $\mathrm{SD}=0.28$ ). Bhuyanpara forest workers helped researchers and students in survey activities, counting animals for census and in camera trapping survey of tiger. Assisting in computer data entry was not considered part of survey job activities.

The items where they scored low were

- $\quad$ Assisting in computer data entry 
- $\quad$ Camera trapping survey of tigers

\section{Conservation:}

Forests not only provide wood but they directly control floods, drought, soil erosion, etc. Conservation of forests is a vital importance for India. A mature tree releases oxygen, checks air pollution, controls moisture, prevents water pollution, prevents soil erosion, increases soil fertility and provides shelter to birds and nests.

\begin{tabular}{|l|l|l|}
\hline \multicolumn{1}{|c|}{ Items } & \multicolumn{1}{|c|}{ Mean } & SD \\
\hline $\begin{array}{l}\text { Help to Reduce human-animal } \\
\text { conflict }\end{array}$ & 2.11 & 1.73 \\
\hline $\begin{array}{l}\text { Educating communities on } \\
\text { wildlife conservation }\end{array}$ & 1.20 & 1.47 \\
\hline $\begin{array}{l}\text { Have knowledge on tourism \& } \\
\text { tourist activities and wildlife } \\
\text { conservation }\end{array}$ & 1.81 & 1.52 \\
\hline
\end{tabular}

Table 5:Items under conservation domain under job analysis

As seen above, forest workers felt conservation as relatively less frequent activities in their job duties(M=1.43,SD=0.24).Like other domains, forest workers of Bhuyanpara $(\mathrm{M}=1.54, \mathrm{SD}=0.16)$ performed more conservation activities than their counterparts $(\mathrm{M}=1.33, \mathrm{SD}=0.40)$.even though the forest workers felt conservation was not a main activity, yet it was observed that the forest workers did conserve the animals by reducing humananimal conflict and giving knowledge about wildlife conservation to the tourists and the communities.

The items where they scored low were:

- Scheduled plan of burning grass for forest management

- Maintenance of power fencing in boundaries

- Have knowledge on tourism \& tourist activities and wildlife conservation

\section{Working conditions:}

Working condition was assessed with 13 Yes-No type items.Results reveal that forest workers were deprived of the basic needs like getting drinking water, toilet, $(\mathrm{M}=1.10, \mathrm{SD}=0.30)$, working without wireless communication( $\mathrm{M}=1.11, \mathrm{SD}=0.31)$, weapons as well as medical care. This was also reflected in the FGD where they mentioned regarding lack of medical care or emergency services if injured during duty hours, unhygienic living conditions like lack of clean drinking water, toilets, cleaning agents and cooking facilities. They also expressed the lack of recreation facilities or activities after duty hours. 


\begin{tabular}{|l|l|}
\hline \multicolumn{3}{|c|}{ Favourable Working Condition } \\
\hline Yes & \multicolumn{1}{|c|}{ No } \\
\hline $38(46 \%)$ & $44(54 \%)$ \\
\hline
\end{tabular}

Table 6: Perception of Working Condition

The questionnaire had an open ended question on how the forest workers can improve their lives. They statements to this were collated and the highest frequency statements were taken down. The list of which is given below:

- $\quad$ Become dedicated worker

- Avail better infrastructure and updated equipment like ammunitions, radio operative system, vehicle

- $\quad$ Avail permanent job/salary/promotion

- $\quad$ Better training from department to help in conservation/protection

- Wants more manpower in the field

- Develop a vegetable garden

- $\quad$ Need better training to help in conservation

- $\quad$ Expect more support from the department

- $\quad$ Take guidance from seniors \& sharing his experience about conservation

- $\quad$ Reduce illegal activities in Manas National Park

- $\quad$ To improve in patrolling duty

- $\quad$ To develop his knowledge about wild plants \& animals

Overall results reflect that the forest workers in Bhuyanpara were more aware of their job profile than Bansbari. ). The forest workers felt that the more important duties were patrolling and monitoring. Conservation and survey are least frequent job activities. It was interesting to note that the forests workers of Bansbari $(\mathrm{M}=1.66, \mathrm{SD}=0.13)$ perceived relatively better working conditions than those of Bhuyanpara $(\mathrm{M}=1.37, \mathrm{SD}=0.14)$

\section{FINDINGS OF SELF EFFICACY OF FOREST WORKERS}

Self-efficacy questionnaire was designed keeping in mind the objective to understand the forest workers self-efficacy towards their work. According to Bandura (1977), self-efficacy is the "belief in one's capabilities to organize and execute the course of action required to manage prospective situation" In other words, self-efficacy is a person's belief in his or her ability to succeed in a particular situation. Bandura described these beliefs as determinants of how people think, behave and feel. Moods, emotional states, physical reactions and stress level can all impact how a person feels about their personal abilities in a particular situation. This is a pivotal component of social cognitive theory in that beliefs of personal efficacy determine the acquisition of knowledge on which skills are 
founded. Thus by learning how to minimize stress and elevate mood when facing difficult or challenging tasks, people can improve their sense of self efficacy.

There were in total five domains in the questionnaire, namely Patrolling Efficacy, Monitoring Efficacy, Survey Efficacy, Conservation Efficacy and Vicariousnessand Control over emotions and Physiological changes. The responses were analysed and their frequency and percentage were taken out.

\begin{tabular}{|l|l|l|l|l|l|l|l|l|l|l|}
\hline \multicolumn{10}{|c|}{ Efficacy } \\
\hline & \multicolumn{2}{|c|}{ Patrolling } & \multicolumn{2}{|c|}{ Monitoring } & \multicolumn{2}{|c|}{ Survey } & \multicolumn{2}{c|}{ Conservation } & \multicolumn{2}{c|}{ Emotional Changes } \\
\hline Range & Mean & SD & Mean & SD & Mean & SD & Mean & SD & Mean & SD \\
\hline Bhuyanpara & 3.20 & 1.57 & 3.46 & 1.24 & 2.13 & 1.87 & 2.92 & 1.63 & 3.89 & 0.70 \\
\hline Bansbari & 3.20 & 1.61 & 3.74 & 1.03 & 2.27 & 1.84 & 2.88 & 1.56 & 3.95 & 0.90 \\
\hline
\end{tabular}

Table 7: Domain-wise efficacy of the two ranges

Forest workers are adaptive with their emotional stress $(\mathrm{M}=3.73, \mathrm{SD}=0.80)$. In relation to their efficacy in core job activities, highest efficacy was observed in monitoring. They felt less efficacy in survey $(\mathrm{M}=2.32, \mathrm{SD}=1.85)$, conservation $(\mathrm{M}=2.90, \mathrm{SD}=1.60)$ and patrolling $(\mathrm{M}=3.20, \mathrm{SD}=1.59)$. Similar results were obtained from both the ranges. With respect to between range differences, forest workers were more efficacious in monitoring in Bansbari( $\mathrm{M}=3.74, \mathrm{SD}=1.03)$ than those of Bhunyapara.

Some of the areas of job analysis which they have scored low are listed below. Though the senior officers expressed these activities were important elements of their job profile, the forest guards were not confident about these activities.

\section{Patrolling Efficacy:}

- $\quad$ Using GPS and other equipment during patrolling

- $\quad$ Understanding the typical habitats

- $\quad$ Ambushing \&interrogate poachers \& intruders

- $\quad$ Preparing documents for court case against poacher

- $\quad$ Brief, debriefing patrol duties and maintaining patrol reports and submit to RO

\section{Monitoring Efficacy}

- Knowledge on vegetation

- $\quad$ Protecting workers \&labour involved in park infrastructure work 


\section{Survey Efficacy}

- $\quad$ Reading maps

- $\quad$ Assisting in computer data entry

- $\quad$ Camera trapping for survey of tigers

\section{Conservation Efficacy and Vicariousness}

- $\quad$ Maintaining power fencing in boundaries

- $\quad$ Helping to ward off wild animals from paddy fields

- $\quad$ Knowledge on forest management\&wildlife conservation

\section{DISCUSSION}

The forest workers of Manas are an aging work force with more than $80 \%$ of the workers above the age of 35 years. Most of the staff has completed minimum of 12 years services to maximum 25 to 28 years of service. Some respondents have completed 25 years and above service in Manas Wildlife Conservation without transfer to other sanctuary in the state. This also correlates with their statement in FGD about not getting a transfer from one sanctuary to another. On the other hand, the young group in the service range of 5 to 10 years with age 25 to 35 years have not received any induction training and are mostly unaware of the job profile. This signifies that the work force is moving towards retirement age while new recruits to substitute them are not in place.

In regard to the educational qualification of the forest workers, 59\% of the respondents are High School pass, followed by the $22 \%$ who have only attended school. Out of 82 respondents, only $6 \%$ have completed graduation. This can act as a barrier to professional growth as new technologies to capture, monitor, survey and conserve wildlife has come into the system and their learning capacity may not be adequate to understand the nuances of these new technologies.

Majority of the respondents belongto Hindu community, from Schedule Caste (48) and Other Backward Caste (21). Of the 82 respondents, $89 \%$ are married with having dependents of 4 to 8 members which includes wife, children, parents, relatives and grandchildren.

Looking at the work life demographics, 65 reported of not getting any promotion during their term of working in Manas National Park. Promotions are limited to change in designation while salary may increase or may not along with it. Most of the promotion was related to their jobs becoming permanent from casual. This was also reflected during the focus group discussion. Only a few have received awards for bravery or for good performance from the government or from NGOs. Some of the recognition are certificate from NGO for catching hog, medal from some Delhi party for well performance during duty, certificate for working with dedication, recognition for capturing poachers, award for dedication known as "Maosawm Hanja Bantha".

Job analysis questionnaire was designed keeping in mind the objective of understanding the job profile and job responsibilities of the forest worker and how aware are they of it. The main role \& responsibilities of the frontline forest staffs are patrolling, monitoring, survey and conservation of 
wildlife in the park. They are also involved in periodic census taking of wildlife, helping researchers in field works and also have to escort and act as guides for the tourists.

Besides that they have to maintain public relations with the surrounding communities around the park and help in the socio economic development of the fringe area community. Thus they have multiple roles to play which however is not defined in their job profile as forest workers. Most workers do not put least preference to conservation, patrolling and survey work. Their self-efficacy questionnaire also reflects that they do not have any confidence on these areas nor the knowledge to carry out these duties

Some of the areas of job analysis which they have scored low are listed below. Though the senior officers expressed these activities were important elements of their job profile, the forest guards did not think of them to be of priority in the jobs.

\section{Patrolling:}

- $\quad$ Counter attacking poachers

- $\quad$ Interrogation of poachers \& intruders

- $\quad$ Protecting animals from injury

- $\quad$ Taking accused (asami) to court

\section{Monitoring:}

- $\quad$ Protection of workers \&labour involved in park infrastructure work

\section{Survey:}

- $\quad$ Counting animals for census

- $\quad$ Camera trapping survey of tigers

\section{Conservation:}

- $\quad$ Maintenance of power fencing in boundaries

- $\quad$ Helping community to ward off wild animals from paddy fields

- $\quad$ Scheduled plan of burning grass for forest management

- Educating communities on wildlife conservation

- Have knowledge on tourism \& tourist activities and wildlife conservation

It was interesting to observe that one of the duties of the forest workers is to ward off outsiders who come and pick wood or cut tress so as to conserve the environment, while it was seen that the forest workers themselves are collecting wood for cooking purposes as there are no other cooking facilities like cooking gas connection or stoves.

The aids and weapons provided to perform their dutiesare out dated, so often, they shy away from chasing poachers. GPS patrolling has come in recently, however no scheduled training is provided to 
use new tools or weapons or in regard to their duties. There is only one induction training. The juniors often learn about their work from the seniors including how to use the weapons. Communication with superiors is rigid and with the top to bottom communication process model being adopted. Feedback is limited to field activity without scope of any lateral discussion or decision making. There is no fixed schedule for their duty or to take leave to meet their families. Most of them have an internal arrangement of taking leave. Promotion system is not in place. Nor there is a system of regular rotation of forest staff from one park to another.

Till date there are more casual workers in the national park. This has affected their sense of belongingness or to lay down any concrete plans for their own futures. This has also made them feel unsecured about the future, as they have families to look after. Most mentioned, especially the younger workers that they are looking for other jobs. Thus retention of manpower becomes an issue. This also brings down the motivation level of the forest workers. In addition to this, the overall wage is low in comparison to the national wage level. Uniforms, Rain coats, boots, torch and other such equipment are not received on time. This causes disruption in their work schedule as well as lowers their quality of life. Travel allowance is not provided, when the forest workers has to travel to court to identify the poachers or for similar work. In case there is an accident or someone is unwell, they have to travel a long distance by foot or by government vehicle which is often not available. No compensation provided for medical emergencies are provided.

Living conditions in the camp sites is abysmal. Per camp there are minimum 5 people to maximum 16 people living together. It also depends on the camp size and the area that is covered. Minimum first aid is available in the camp sites. Fresh drinking water is not available as water filters are not been provided. They have to boil water, cool it down and then use it as drinking water. Bathroom facility is poor and unhygienic. A lot of time is spent on cooking and collecting wood as gas or other cooking amenities are not adequately provided. Proper fencing around the camp sites are not present and hence most of the times their rations and kitchen are attacked by wild animals.

Physical health of the staff is average to poor which was also reflected in the GHQ. Most of them did admit to intake of alcohol to release them of their day's weary and tiredness. Most workers expressed not having job satisfaction and are doing the job as they have nowhere to go. Again since the work force is already in the middle age, they neither lack confidence to decide to change job nor are they trained for any alternative profession or vocation. This is so as most of the workers do not have higher education or have any training for any other skills. So most feel they are trapped in this job.

Interestingly, the General Health Questionnaire (GHQ) which was designed to detect any psychological stress and correlates negatively with global quality of life reflected only 7 out of 82 suffering from psychological distress. This shows that the majority of the population's emotional health is average and they have been able to cope with the stress of the job and the living condition. This is contradictory to the report of the focus group discussion where the respondents have expressed that there are stresses of daily living and feeling low and depressed. They have also expressed their concern about physical and emotional security. Moreover, they do not have any outlet to release stress as there is no facility for outdoor or indoor constructive recreation. Most of them were observed playing carom or cards in their rooms. Thus the tendency to consume alcohol or any substance abuse is higher after work is over. Most mentioned that what keeps in the job is their love for animals and the forest. 
This can be related to resilience and coping skills they may have developed due to the long duration of their tenure in a stressful environment, thereby leading to numbness of feelings \& emotions. Any sign of emotional weakness may reflect poorly on their profession and job. Again, the poor reporting may be due to the lack of experience on the part of the data collectors in collecting data and documenting psychological responses. This may be so as the General Health Questionnaire (GHQ) is slightly complex to explain and as the data collectors were field personnel of Aaranyak who did not much experience in this area of work. The other possibility may be the understanding of the forest workers of the statements, as their highest educational levels was high school pass. Thus on retrospect it is felt that a different questionnaire may have been more effective. However enough data on the mental and emotional health of the forest workers were gathered from the focus group discussion.

Family support was poor, as the forest workers are not allowed to bring their families as it may be a danger to them. There is no fixed schedule for them to visit their families. Telephonic communication is also very poor. This has caused a sense of insecurity which is also reflected in the GHQ as well as in the self-efficacy questionnaire. Most shared that they feel depressed and lonely as they do not have much communication with the outside world.

Self-efficacy questionnaire was designed keeping in mind the objective to understand the forest workers self-efficacy towards their work. Self efficacy is a person's belief in his or her ability to succeed in a particular situation. Bandura described these beliefs as determinants of how people think, behave and feel. Moods, emotional states, physical reactions and stress level can all impact how a person feels about their personal abilities in a particular situation. This is a pivotal component of social cognitive theory in that beliefs of personal efficacy determine the acquisition of knowledge on which skills are founded. Thus by learning how to minimize stress and elevate mood when facing difficult or challenging tasks, people can improve their sense of self efficacy.

There were in total five domains in the questionnaire, namely Patrolling Efficacy, Monitoring Efficacy, Survey Efficacy, Conservation Efficacy and Vicariousness and Control over emotions and physiological changes. The responses were analysed and their frequency and percentage were taken out. Most forest workers felt that they were more confident in monitoring and patrolling activities in comparison to survey and conservation activities. Some of the areas of job analysis which they have scored low are listed below. Though the senior officers expressed these activities were important elements of their job profile, the forest guards did not think of them to be of priority in the jobs.

\section{Patrolling Efficacy}

- $\quad$ I can use GPS and other equipment during patrolling

- I know the typical habitats

- I can ambush poachers confidently

- I can interrogate poachers \& intruders

- I can prepare documents required for court case against poacher

- I can take accused (asami) to court

- $\quad$ I can brief \& debrief patrol duties

- I know how to maintain patrol reports and submit to RO 
- $\quad$ Monitoring Efficacy

- I know how to monitor change in vegetation

- I can protect workers \&labour involved in park infrastructure work

\section{Survey Efficacy}

- I can help researchers \& students in survey activities

- I can map the routes of animal movement

- I can count animals for census

- I can assist in computer data entry

- I know how to do camera trapping survey of tigers

\section{Conservation Efficacy and Vicariousness}

- I can maintain power fencing in boundaries

- I can help community to ward off wild animals from paddy fields

- I know how to schedule burning grass for forest management

- I can educate communities on wildlife conservation

- I have knowledge on tourism \& tourist activities and wildlife conservation

- $\quad$ I am able to imitate successful forest workers

- $\quad$ I have scheduled meetings with my supervisors and seniors

Enhancing the self efficacy of the workers will enable them to minimize stress and elevate mood when facing difficult or challenging tasks. This can be done by providing adequate training in their job responsibilities and their seniors appreciating them when they conduct their job effectively and efficiently.

Based on the FGD, the questionnaires on job analysis and self-efficacy, some key areas where training is required is enumerated below:

- To have increased communication between the senior officers and the forest workers

- To increase their sense of security in regard to their jobs by making most of them permanent.

- $\quad$ This will also help in increasing the motivation of the workers.

- To have on the job training for all forest personnel including the causal, temporary workers

- $\quad$ To have training on use of different weapons

- To have training for physical fitness

- To train on tourism activities and knowledge as most of the time they have to act as tourist guide 
- $\quad$ Training on legal areas related to wildlife and maintaining the park is required.

- $\quad$ Effective use of IEC materials for different groups

- $\quad$ To provide training in Leadership and team building

Overall it can be said that the forest workers are committed to their jobs. They would be able to be more effective and efficient in their jobs provided that their living conditions are improved, recreation facilities are provided and intensive on the job training is given on a regular basis.

\section{LIMITATIONS OF THE SURVEY}

- The usual challenges of mobilization were faced. The data collectors could collect the data only during off duty time

- $\quad$ The data was collected by the field personnel of Aaranyak and some of them were not very equipped to collect information on the GHQ inspite of training imparted to them on all the formats.

- Moreover data collection works were interrupted by the open season of the sanctuary when tourism peaks and the forest workers have to be available in their respective areas to man their multifarious responsibilities. Thus the off season period of the sanctuary was the only feasible time frame selected when the forest workers had more time to interact with the data collectors. Thus there was delay in data collection which pushed the project beyond the stipulated time period.

\section{RECOMMENDATION}

- Induction training to acquaint them to the job profile

- Equal treatment of permanent \& casual workers in regard to other facilities like uniform weapons etc. this will help in enhancement of the self respect and dignity.

- $\quad$ Capacity building on monitoring, conservation and survey

- $\quad$ Provision of uniform, ancillary equipment like raincoat torch GPS etc to be provided on time and given to both permanent \& casual workers

- $\quad$ Provision for games and other sport activities during their off duty hours

- $\quad$ Scheduled breaks for forest workers to meet their families

- Improve living conditions like providing with gas connection, water filter, fencing around the camps to ward of wild animals.

\section{CONCLUSION}

In conclusion it can be said that the forest workers of Manas National Park have been able to carry on their duties inspite of all the issues of safety and security from wild animals and poachers. Their GHQ and self efficacy results showed that their quality of life is adequate even though it was reflected otherwise in the FGD where they have stated that they do feel stress, feels lonely without the family and worry about their physical and mental health. This may be so as most of the respondents have been in the same job and in the same sanctuary from the time they have started their service life. So a sense of complacency and resignation to faith may have taken place. This also reflects on their lack of 
motivation to go the extra mile to be look after the sanctuary and protect it from poachers or learn new technologies to protect the park. The news on capturing are still on even after we had taken the survey.

The organisation Aaranyak has been a great source of support to the forest workers in regard to teaching them new techniques of camera trapping of animals, census of animals and to bring the surrounding community closer to the forest workers. Aaranyak with the support of the senior forest officials can provide periodic training to the forest workers on aspects of conservation, survey and monitoring of wildlife in the parkthereby improve the quality of life of the forest workers. This will help to enhance their personnel effectiveness, leading to professional excellence. .

\section{REFERENCE}

[1]. https://research-methodology.net/sampling-in-primary-data-collection/purposive-sampling/

[2]. https://www.statisticssolutions.com/general-health-questionnaire-ghq/

[3]. https://en.wikipedia.org/wiki/Quality_of_life

[4]. World Happiness report; Edited by John Helliwell, Richard Layard and Jeffrey Sachs, University of Columbia

[5]. Measuring quality of life; The world health organization; 1997. 


\section{ANNEXURES:}

Annexure 1: Format on Demographic Profile of Forest Personnel of Manas National Park

\begin{tabular}{|c|c|c|c|c|c|c|c|}
\hline Range & Bansbari & Panbari & Bhuyanpara & \multirow{2}{*}{$\begin{array}{l}\text { Camp } \\
\text { Gender }\end{array}$} & & & \\
\hline Name & & & & & $\mathrm{M}$ & $\mathrm{F}$ & \\
\hline Designation & Ranger & $\begin{array}{l}\text { Deputy } \\
\text { Ranger }\end{array}$ & Forester & $\begin{array}{l}\text { Forest } \\
\text { Guard }\end{array}$ & Mahut & Ghasi & \\
\hline $\begin{array}{l}\text { Monthly } \\
\text { Income }\end{array}$ & $<5000$ & \multicolumn{2}{|c|}{$5000-10000$} & $000-$ & $15000-20000$ & & $20000-25000$ \\
\hline $\begin{array}{l}\text { Period of } \\
\text { service in the } \\
\text { department } \\
\text { (yrs) }\end{array}$ & $0-5$ & $5-10$ & $10-15$ & $15-20$ & $20-25$ & & \\
\hline $\begin{array}{l}\text { Period of } \\
\text { service in } \\
\text { manas(yrs) }\end{array}$ & $0-2$ & $2-5$ & $5-10$ & $10-15$ & $15-20$ & & \\
\hline \multicolumn{8}{|c|}{ Last promotion/ reward/ praise from senior/govt/ngo/etc ( give details) } \\
\hline $\begin{array}{l}\text { Education } \\
\text { level }\end{array}$ & Master & Graduate & HSSLC & HSLC & $\begin{array}{l}\text { High } \\
\text { School }\end{array}$ & $\begin{array}{l}\text { Attended } \\
\text { School }\end{array}$ & $\begin{array}{l}\text { Never } \\
\text { Attended } \\
\text { School }\end{array}$ \\
\hline Category & General & $\mathrm{SC}$ & ST & OBC & $\begin{array}{l}\text { Other } \\
\text { (specify) }\end{array}$ & & \\
\hline Community & Hindu & Muslim & Christian & $\begin{array}{l}\text { Other } \\
\text { (specify) }\end{array}$ & & & \\
\hline Marital status & Married & Single & Separated & Divorced & & & \\
\hline $\begin{array}{l}\text { Type } \\
\text { family }\end{array}$ & Nuclear & Joint & Extended & $\begin{array}{l}\text { Other } \\
\text { (specify) }\end{array}$ & & & \\
\hline $\begin{array}{l}\text { No.of } \\
\text { children }\end{array}$ & $\mathrm{M}$ & $F$ & $\begin{array}{l}\text { Other } \\
\text { dependents }\end{array}$ & $\begin{array}{l}\text { Father } \\
\text { Sister/ oth }\end{array}$ & $\begin{array}{l}\text { Mother /H } \\
\text { er(Specify) }\end{array}$ & rother & \\
\hline $\begin{array}{l}\text { Education of } \\
\text { children }\end{array}$ & $\begin{array}{l}\text { Primary } \\
\text { School }\end{array}$ & $\begin{array}{l}\text { High } \\
\text { School }\end{array}$ & $\begin{array}{l}\text { Higher } \\
\text { Secondary }\end{array}$ & College & University & & \\
\hline $\begin{array}{l}\text { Wife's } \\
\text { education }\end{array}$ & Master & Graduate & HSSLC & HSLC & & & \\
\hline $\begin{array}{l}\text { Wife's } \\
\text { occupation }\end{array}$ & Housewife & $\begin{array}{l}\text { Govt. } \\
\text { Service }\end{array}$ & Pvt. Service & $\begin{array}{l}\text { Other } \\
\text { (specify) }\end{array}$ & $\begin{array}{l}\text { High } \\
\text { School }\end{array}$ & $\begin{array}{l}\text { Attended } \\
\text { School }\end{array}$ & $\begin{array}{l}\text { Never } \\
\text { Attended } \\
\text { School }\end{array}$ \\
\hline $\begin{array}{l}\text { Income } \\
\text { wife }\end{array}$ & $<5000$ & $\begin{array}{l}5000 \\
10000\end{array}$ & $\begin{array}{l}10000- \\
15000\end{array}$ & $\begin{array}{l}15000- \\
20000\end{array}$ & $\begin{array}{l}20000- \\
25000\end{array}$ & & \\
\hline
\end{tabular}




\section{Annexure 2: Questions for Focus Group Discussion}

\section{Work related:}

Are you aware of the various forest management and conservation practices used in MNP? Can you name a few

In your opinion, what are the policies undertaken in this park for wildlife protection and conservation According to you, what are the basic requirements in a camp?

What is available now?

Have you received training?

What kind of training have you received?

According to you what kind of training do you require?

Have you visited other game parks and sanctuaries? If yes, name them

\section{Communication \& Interpersonal relationship at work:}

Is your communication with your seniors satisfactory?

What kind of support is provided by your seniors to assist you in your work?

Is it adequate? If not, what additional support do you need?

What kind of support is provided by your colleagues in your work?

Is it adequate? If not, what additional support do you need?

How often do you communicate with people surrounding the park?

Do you provide any support to the communities around the park? If yes what kind?

\section{Personal:}

Do you have access to basic facilities like periodic health check up, medical support, housing for you and your family members

How often do you get leave?

According to you, is the work environment satisfactory?

If not, what according to you what needs to be done?

What do you think needs to be done to make Manas National Park an attractive tourist spot 


\section{Annexure 3: Questionnaire for Job Analysis of Forest Workers}

Forest worker job includes several activities. You perform some regularly, some less frequently and some activities may not be applicable for your job category. Below are some activities. Rate them in terms of following five rating categories.

Rate 0: not applicable

Rate 1: least frequently

Rate 2: less frequently

Rate 3: sometimes

Rate 4: more frequently

Rate 5: most frequently

\begin{tabular}{|l|l|l|l|l|l|l|}
\hline Items & 0 & 1 & 2 & 3 & 4 & 5 \\
\hline Counter attacking to aggressive animals & 0 & 1 & 2 & 3 & 4 & 5 \\
\hline Identifying different pug marks of animals & 0 & 1 & 2 & 3 & 4 & 5 \\
\hline Tracking movement of animals & 0 & 1 & 2 & 3 & 4 & 5 \\
\hline Helping researchers \& students in survey activities & 0 & 1 & 2 & 3 & 4 & 5 \\
\hline Help to Reduce human-animal conflict & 0 & 1 & 2 & 3 & 4 & 5 \\
\hline Knowing the typical habitats & 0 & 1 & 2 & 3 & 4 & 5 \\
\hline Monitoring animal movement & 0 & 1 & 2 & 3 & 4 & 5 \\
\hline Mapping the routes of animal movement & 0 & 1 & 2 & 3 & 4 & 5 \\
\hline Maintenance of power fencing in boundaries & 0 & 1 & 2 & 3 & 4 & 5 \\
\hline Using GPS and other equipment during patrolling & 0 & 1 & 2 & 3 & 4 & 5 \\
\hline Monitoring change in vegetation & 0 & 1 & 2 & 3 & 4 & 5 \\
\hline Counting animals for census & 0 & 1 & 2 & 3 & 4 & 5 \\
\hline Helping community to ward off wild animals from paddy fields & 0 & 1 & 2 & 3 & 4 & 5 \\
\hline Counter attacking poachers & 0 & 1 & 2 & 3 & 4 & 5 \\
\hline Protection of workers \& labour involved in park infrastructure work & 0 & 1 & 2 & 3 & 4 & 5 \\
\hline Assisting in computer data entry & 0 & 1 & 2 & 3 & 4 & 5 \\
\hline Scheduled plan of burning grass for forest management & 0 & 1 & 2 & 3 & 4 & 5 \\
\hline Ambushing poachers & 0 & 1 & 2 & 3 & 4 & 5 \\
\hline Camera trapping survey of tigers & 0 & 1 & 2 & 3 & 4 & 5 \\
\hline Educating communities on wildlife conservation & 0 & 1 & 2 & 3 & 4 & 5 \\
\hline Interrogation of poachers \& intruders & & 3 & 4 & 5 \\
\hline
\end{tabular}




\begin{tabular}{|c|c|c|c|c|c|c|}
\hline $\begin{array}{l}\text { Have knowledge on tourism \& tourist activities and wildlife } \\
\text { conservation }\end{array}$ & 0 & 1 & 2 & 3 & 4 & 5 \\
\hline Guarding people's movement in and around the park & 0 & 1 & 2 & 3 & 4 & 5 \\
\hline Protecting animals from injury & 0 & 1 & 2 & 3 & 4 & 5 \\
\hline Taking accused (asami) to court & 0 & 1 & 2 & 3 & 4 & 5 \\
\hline Escorting officers and tourist & 0 & 1 & 2 & 3 & 4 & 5 \\
\hline Briefing \& debriefing of patrolling duties & 0 & 1 & 2 & 3 & 4 & 5 \\
\hline Submitting \& maintaining patrol duties & 0 & 1 & 2 & 3 & 4 & 5 \\
\hline Maintaining personal weapons & 0 & 1 & 2 & 3 & 4 & 5 \\
\hline Have protocol for patrol duties & 0 & 1 & 2 & 3 & 4 & 5 \\
\hline WORKING CONDITIONS & & & & & & \\
\hline Conveyance facility within the park & Yes & & & No & & \\
\hline Working without wireless communication & Yes & & & No & & \\
\hline Have provision for shift duty and leave & Yes & & & No & & \\
\hline Difficult to receive emergency response or rescue during duty & Yes & & & No & & \\
\hline Have provision to maintain health, hygiene and cleanliness in camps & Yes & & & No & & \\
\hline Have waste disposal system in camps & Yes & & & No & & \\
\hline $\begin{array}{l}\text { Maintenance of safety and security measures around camp sites like } \\
\text { fencing etc. }\end{array}$ & Yes & & & No & & \\
\hline Coping with work related pressure and stress & Yes & & & No & & \\
\hline Getting support of supervisors and officers during duty & Yes & & & No & & \\
\hline $\begin{array}{l}\text { Getting uniforms, protective gears like torch, torch batteries, gum } \\
\text { boots, raincoats provided on time }\end{array}$ & Yes & & & No & & \\
\hline Getting medical care from departmentif injured during duty hours & Yes & & & No & & \\
\hline $\begin{array}{l}\text { Getting drinking water, toilets, cleaning agents, cooking facilities } \\
\text { etc. }\end{array}$ & Yes & & & No & & \\
\hline Getting recreation facilities or activities after duty hours & Yes & & & No & & \\
\hline \multicolumn{7}{|l|}{ How would you like to improve your life as a forest worker? } \\
\hline \multicolumn{7}{|l|}{ Data collected by: } \\
\hline \multicolumn{7}{|l|}{ Contact No: } \\
\hline
\end{tabular}




\section{Annexure 4: Questionnaire on Self-Efficacy of Front Line Forest Workers}

Below is the list of activities. Read each statement and rate them to indicate how extent you believe them.

5: Very high extent

4. High extent

3. Undecided

2. Low extent

1. Very low extent

\begin{tabular}{|c|c|c|c|c|c|c|}
\hline Items & 0 & 1 & 2 & 3 & 4 & 5 \\
\hline I can counter attack aggressive animals & 0 & 1 & 2 & 3 & 4 & 5 \\
\hline I can identify different pug marks of animals & 0 & 1 & 2 & 3 & 4 & 5 \\
\hline I can help researchers \& students in survey activities & 0 & 1 & 2 & 3 & 4 & 5 \\
\hline I know the typical habitats & 0 & 1 & 2 & 3 & 4 & 5 \\
\hline I know how to monitor animal movement & 0 & 1 & 2 & 3 & 4 & 5 \\
\hline I can map the routes of animal movement & 0 & 1 & 2 & 3 & 4 & 5 \\
\hline I can use GPS and other equipments during patrolling & 0 & 1 & 2 & 3 & 4 & 5 \\
\hline I know how to monitor change in vegetation & 0 & 1 & 2 & 3 & 4 & 5 \\
\hline I can count animalsfor census & 0 & 1 & 2 & 3 & 4 & 5 \\
\hline I can counter attack poachers & 0 & 1 & 2 & 3 & 4 & 5 \\
\hline $\begin{array}{l}\text { I can protect workers \&labour involved in park } \\
\text { infrastructure work }\end{array}$ & 0 & 1 & 2 & 3 & 4 & 5 \\
\hline I can assist in computer data entry & 0 & 1 & 2 & 3 & 4 & 5 \\
\hline I can ambush poachers confidently & 0 & 1 & 2 & 3 & 4 & 5 \\
\hline I know how to do camera trapping surveyof tigers & 0 & 1 & 2 & 3 & 4 & 5 \\
\hline I can interrogate poachers \& intruders & 0 & 1 & 2 & 3 & 4 & 5 \\
\hline $\begin{array}{l}\text { I can prepare documents required for a court case against a } \\
\text { poacher }\end{array}$ & 0 & 1 & 2 & 3 & 4 & 5 \\
\hline I can check people's movement in and around the park & 0 & 1 & 2 & 3 & 4 & 5 \\
\hline I can take accused (asami) to court & 0 & 1 & 2 & 3 & 4 & 5 \\
\hline I can escort officers and tourist & 0 & 1 & 2 & 3 & 4 & 5 \\
\hline I can brief \& debrief patrol duties & 0 & 1 & 2 & 3 & 4 & 5 \\
\hline I know how to maintain patrol reports and submit to RO & 0 & 1 & 2 & 3 & 4 & 5 \\
\hline I know how to use and maintain my service weapon & 0 & 1 & 2 & 3 & 4 & 5 \\
\hline I know the protocol for patrol duties & 0 & 1 & 2 & 3 & 4 & 5 \\
\hline I can maintain power fencing in boundaries & 0 & 1 & 2 & 3 & 4 & 5 \\
\hline $\begin{array}{l}\text { I can help community to ward off wild animals from paddy } \\
\text { fields }\end{array}$ & 0 & 1 & 2 & 3 & 4 & 5 \\
\hline $\begin{array}{l}\text { I know how to schedule burning grass for forest } \\
\text { management }\end{array}$ & 0 & 1 & 2 & 3 & 4 & 5 \\
\hline I can educate communities on wildlife conservation & 0 & 1 & 2 & 3 & 4 & 5 \\
\hline $\begin{array}{l}\text { I have knowledge on tourism \& tourist activities and } \\
\text { wildlife conservation }\end{array}$ & 0 & 1 & 2 & 3 & 4 & 5 \\
\hline I am able to imitate successful forest workers & 0 & 1 & 2 & 3 & 4 & 5 \\
\hline I am able to apply experience of successful forest workers & 0 & 1 & 2 & 3 & 4 & 5 \\
\hline
\end{tabular}




\begin{tabular}{|l|l|l|l|l|l|l|}
\hline I am able to ask other's advice during crisis & 0 & 1 & 2 & 3 & 4 & 5 \\
\hline I can apply my training \& job knowledge successfully & 0 & 1 & 2 & 3 & 4 & 5 \\
\hline I can follow my superior's order & 0 & 1 & 2 & 3 & 4 & 5 \\
\hline I am able to satisfy my superiors at work & 0 & 1 & 2 & 3 & 4 & 5 \\
\hline I have scheduled meetings with my supervisors and seniors & 0 & 1 & 2 & 3 & 4 & 5 \\
\hline I can control my anger & 0 & 1 & 2 & 3 & 4 & 5 \\
\hline I can cope with interpersonal conflict among my colleagues & 0 & 1 & 2 & 3 & 4 & 5 \\
\hline I can overcome my worry on my own & 0 & 1 & 2 & 3 & 4 & 5 \\
\hline I can help others to overcome anxiety & 0 & 1 & 2 & 3 & 4 & 5 \\
\hline I can name a few hobbies that helps to keep me occupied & 0 & 1 & 2 & 3 & 4 & 5 \\
\hline I can control using intoxicating substance & 0 & 1 & 2 & 3 & 4 & 5 \\
\hline I am satisfied with my present job & 0 & 1 & 2 & 3 & 4 & 5 \\
\hline I can cope well in the camp without my family & 0 & 1 & 2 & 3 & 4 & 5 \\
\hline
\end{tabular}

Annexure 5: General Health Questionnaire (GHQ) 12

\begin{tabular}{|c|c|c|c|c|}
\hline Have you recently: & & & & \\
\hline $\begin{array}{l}\text { Been able to concentrate on } \\
\text { whatever you're doing? }\end{array}$ & $\begin{array}{l}\text { Better than } \\
\text { usual }\end{array}$ & $\begin{array}{l}\text { Same } \\
\text { usual }\end{array}$ & $\begin{array}{l}\text { Worse than } \\
\text { usual }\end{array}$ & $\begin{array}{l}\text { Much worse } \\
\text { than usual }\end{array}$ \\
\hline Lost much sleep over worry? & Not at all & $\begin{array}{l}\text { No more } \\
\text { than usual }\end{array}$ & $\begin{array}{l}\text { Rather more } \\
\text { than usual }\end{array}$ & $\begin{array}{l}\text { Much more } \\
\text { than usual }\end{array}$ \\
\hline $\begin{array}{l}\text { Felt that you are playing a useful part } \\
\text { in things? }\end{array}$ & $\begin{array}{l}\text { More so } \\
\text { than usual }\end{array}$ & $\begin{array}{l}\text { Same } \\
\text { usual }\end{array}$ & $\begin{array}{l}\text { Less useful } \\
\text { than usual }\end{array}$ & $\begin{array}{l}\text { Much } \\
\text { useful }\end{array}$ \\
\hline $\begin{array}{l}\text { Felt capable of making decisions } \\
\text { about things? }\end{array}$ & $\begin{array}{l}\text { More so } \\
\text { than usual }\end{array}$ & $\begin{array}{l}\text { Same } \\
\text { usual }\end{array}$ & $\begin{array}{l}\text { Less useful } \\
\text { than usual }\end{array}$ & $\begin{array}{l}\text { Much } \\
\text { useful }\end{array}$ \\
\hline Felt constantly under strain? & Not at all & $\begin{array}{l}\text { No more } \\
\text { than usual }\end{array}$ & $\begin{array}{l}\text { Rather more } \\
\text { than usual }\end{array}$ & $\begin{array}{l}\text { Much more } \\
\text { than usual }\end{array}$ \\
\hline $\begin{array}{l}\text { Felt you couldn't overcome your } \\
\text { difficulties? }\end{array}$ & Not at all & $\begin{array}{l}\text { No more } \\
\text { than usual }\end{array}$ & $\begin{array}{l}\text { Rather more } \\
\text { than usual }\end{array}$ & $\begin{array}{l}\text { Much more } \\
\text { than usual }\end{array}$ \\
\hline $\begin{array}{l}\text { Been able to enjoy your normal day } \\
\text { to day activities? }\end{array}$ & $\begin{array}{l}\text { More so } \\
\text { than usual }\end{array}$ & $\begin{array}{l}\text { Same } \\
\text { usual }\end{array}$ & $\begin{array}{l}\text { Less useful } \\
\text { than usual }\end{array}$ & $\begin{array}{l}\text { Much } \\
\text { useful }\end{array}$ \\
\hline $\begin{array}{l}\text { Been able to face up to your } \\
\text { problem? }\end{array}$ & $\begin{array}{l}\text { More so } \\
\text { than usual }\end{array}$ & $\begin{array}{l}\text { Same } \\
\text { usual }\end{array}$ & $\begin{array}{l}\text { Less useful } \\
\text { than usual }\end{array}$ & $\begin{array}{l}\text { Much } \\
\text { useful }\end{array}$ \\
\hline $\begin{array}{l}\text { Been feeling unhappy and } \\
\text { depressed? }\end{array}$ & Not at all & $\begin{array}{l}\text { No more } \\
\text { than usual }\end{array}$ & $\begin{array}{l}\text { Rather more } \\
\text { than usual }\end{array}$ & $\begin{array}{l}\text { Much more } \\
\text { than usual }\end{array}$ \\
\hline Been losing confidence in yourself? & Not at all & $\begin{array}{l}\text { No more } \\
\text { than usual }\end{array}$ & $\begin{array}{l}\text { Rather more } \\
\text { than usual }\end{array}$ & $\begin{array}{l}\text { Much more } \\
\text { than usual }\end{array}$ \\
\hline $\begin{array}{l}\text { Been thinking of yourself as a } \\
\text { worthless person? }\end{array}$ & Not at all & $\begin{array}{l}\text { No more } \\
\text { than usual }\end{array}$ & $\begin{array}{l}\text { Rather more } \\
\text { than usual }\end{array}$ & $\begin{array}{l}\text { Much more } \\
\text { than usual }\end{array}$ \\
\hline $\begin{array}{l}\text { Been feeling reasonably happy, all } \\
\text { things considered? }\end{array}$ & $\begin{array}{l}\text { More so } \\
\text { than usual }\end{array}$ & $\begin{array}{l}\text { Same } \\
\text { usual }\end{array}$ & $\begin{array}{l}\text { Less useful } \\
\text { than usual }\end{array}$ & $\begin{array}{l}\text { Much } \\
\text { useful }\end{array}$ \\
\hline
\end{tabular}

